Portland State University

PDXScholar

8-13-1970

\title{
The Effect of Perceptual-Motor Training on Maladaptive Behaviors of Emotionally Disturbed Children
}

Julia Frances Hall

Portland State University

Follow this and additional works at: https://pdxscholar.library.pdx.edu/open_access_etds

Part of the Applied Behavior Analysis Commons, Child Psychology Commons, and the Experimental Analysis of Behavior Commons

Let us know how access to this document benefits you.

\section{Recommended Citation}

Hall, Julia Frances, "The Effect of Perceptual-Motor Training on Maladaptive Behaviors of Emotionally Disturbed Children" (1970). Dissertations and Theses. Paper 1472.

https://doi.org/10.15760/etd.1471

This Thesis is brought to you for free and open access. It has been accepted for inclusion in Dissertations and Theses by an authorized administrator of PDXScholar. Please contact us if we can make this document more accessible: pdxscholar@pdx.edu. 
AN ABSTRACT OS THE THESIS OF Julia Pranees Hall for the Master of

Science in Psychology presented Ausust 13, 1970.

Title: The Efect of Perceptual-Motor Training on Maladiptive

Behaylors of Emot Lonally Disturbed Childxer.

APRRONE EY MEHBES OE THE THES IS CCHITTES:

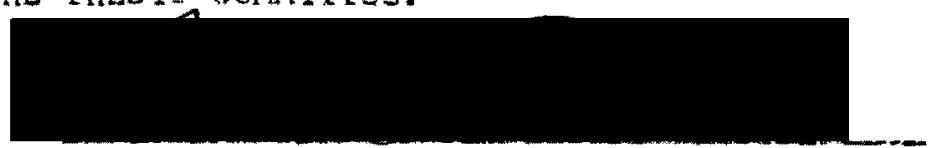

Renald E. Sinich, Chàrinan
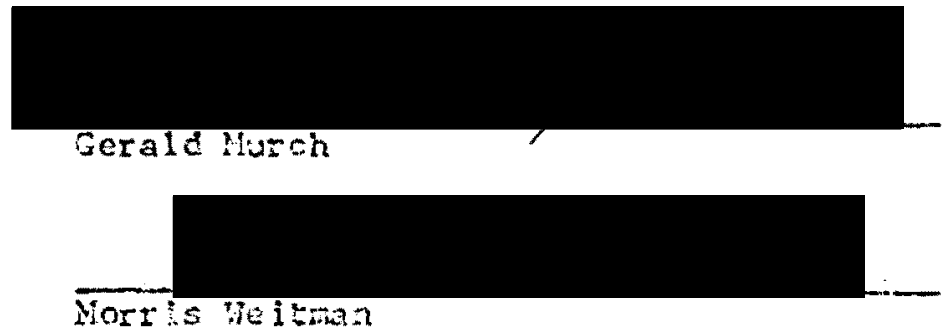

Twenty cmotfonally disturbed chilcren between the ager of six

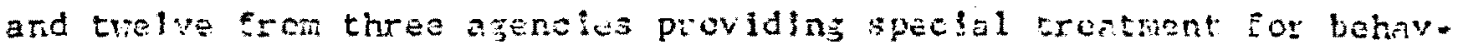
loral or enotional probleins ware the subjects for this study. The sunjects were divided into two najor fiagnostic categotes, withdrawn and acting out, and ther matched in pairs by age and diagnosis. One half of each pair was randonly assigned to the experinental condition and the renaing halves were assigned to the control coacitlon. Both the exper trental and control groups contalned five withdravi and five acting cut subjects. Four experimenters were used, and eacli oxperis nenter workeo with two on sour experinental chlicen and their natehod control subjects.

The Purdug Ferceptual-fotor Survey was arministored to all the subjects prior to the experiment and bekevior rating of maledactive behaviors was obtained on each child from thee adults who worked closely with the shild. vsing the nuthods outined by kepiert and Rader in "Success Tirough Play", the experinental subjects recolved 
perceptual-motor tralning for one-nalf hour three times a week for nine weeks. The control subjects recelved individual adult attention for the same amount of time as the training in the form of physical on quiet activities and games.

At the end of the nine weeks the subjects were tested with the Purdue Perceptual-Notor Survey again and new behavior ratings also were obtained. The behavior scale was analyzed as a total score and then two subscores were obtalned for anti-soclal and asocial behaviors. Analysis revealed that: 1) The experimental subjects perceptualmotor scores increased the most, especlally among the withdawn subjects; 2) The training had littie effect on the maladiptive behaviors of the acting out subjects. The experimental acting out subjects Improved behavforally, but not slgnificantly more than the control acting out subjects; 3) The training had a signiflcant effect on the maladaptive behaviors of withdrawn children. The total behavior scores and the asoclai behavior scores of the experimental withdrawn chlldren improved; the ir anti-social scores changed very little,

The subjects came from three agencies with differant treatment philosophles. One agency was a public school with special classrcoms for emotionally disturbed children which exclusively used behavior modification techniques. Another agency was a residential treasment center which was designed for a milleu therapy, where the children are removed from the home. The third agency was a semi-residential treatment center that used a comblnation of millieu therapy and behavior modification techniques, where the children return home fo: weekends. There were equal numbers of acting out, withdrawn, exper1mental ane control subjects from any single agency. An analysis of the amount of behavioral improvement within each agency was performed which revealed that there was significantly more improvement among the subjects from the semimzesidential trcatment agency.

It was concluded from this study that; perceptual-motor trainIng increases the perceptual-motor abilities of enotionaily disturbed children, especlally those dlagnosed as withdrawn, chlldhood schlzophrenic and autistic; perceptual-motor tralning aids in reducing mala- 
daptive behaviors in disturbed children diagnosed as withdrawn, childhood schizophrenic and autistic; perceptual-motor training may most effectively be used for emotionally disturbed children in conjunction with other forms of treatment. 
THE EFFECT OF PERCEPTUAL-MOTOR TRAIHING ON MALADAPTIVE BEHAVIORS OF EMOTIONALLY DISTURBED CHILDREN

\section{by}

JULIA FRANCES HALL

A thesis submitted in partial fulfillment of the requirements for the degree of

MASTER'S OF SCIENCE

in

PSYCHOLOGY

Portland State University

1970 
TO THE OFF ICE OF GRADUATE STUDIES:

The members of the Comittee approve the thesis of

Julla Frances Hall presented Auzust 13, 1970.

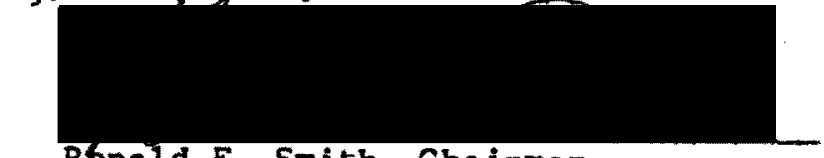

R6nald E. Smith, Chairman

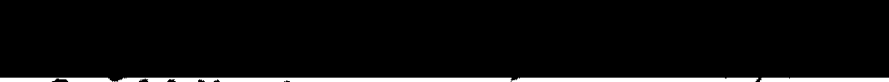

Gerald Nurch

Horris Weitman

APPROVED:

Robert E. Jones, 46 ad, Department of Psychology

Frank/Roberts, Acting Dean of Graduate Students

August 13, 1970 


\section{DEDICATION}

Tc my maternal grandmother, Laura E. Letis, for many years of encouragement and financial aid, which has made this possible. 


\section{ACKNON EVGENENTS}

It is a common practice in witing acknowledgenents to recognize the help of people who have contributed to the study. There were mary people who contributed directly and indirectly to this study by the ir desire and efforts to find more effective methods to treat chldren with emotional and behavioral problems. The following people and organizations are recoynized with a deep sense of gratltude and appreclation.

Acknowledgement is made to the Department of Psychology a: Portland State University, and to my advisors, Ronald Smith, Gerald Murch, and Morr is Wetmon. Special gratitude is mado to Barbara Welner, a professor and friend, whose lnweresi and guidsnee on numerous occasions was greatly apprelcated.

Acknowledgements are mado to 42 asonctes which participated in this study. The ir cooperation was desply appreclated thereby, maing this study posstble: Edgefield Lodge, Waverly Childrens Hone, the Parkrose Project, and Parry Center fo: Children. Special appredation goes to staff members at these ageneles for their patfenee and ccopera. tion.

Appreclation is made to my assistants, Nick Kreofsky, Barbara Morr is and Karen Erom, without whose help this study would not lave been posisto. SFecial gretitude and appreclation ls made to vickl coffey for her encouragement and many hours of typing. 
TABLE OF CONTENTS

PAGE

ACKNOWLEDGEMENTS -

LIST OF TABLES -...... vii

LIST OF FIGURES -

CHAPTER

I INTRODUCTION AND THEORETICAL BACKGROUND

II PROCEDURES - 5

Sampling and Assignment -

Testing and Rating Procedures .......................... 6

Reliability of the Behavior Rating Scale

Validity of the Behavior Sub-tests

Training Procedures for Experimental subjects ..... 9

Angels-in-the-snow

Walking Board

Balance Board

Drawing Games

Pegboard

Marsden Bal1

Procedures for Control Subjects _.................. 13

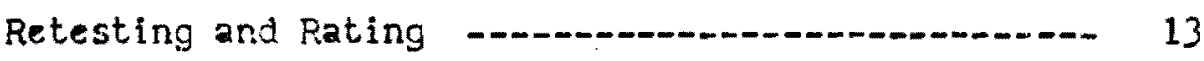

Hypotheses -

III RESULTS - -

Reliability of the Behavior Rating Scale _.......... 15

Analyses - -

Analysis of Ferceptual-Motor Change

Analysis of Behavi or Change

Analysis of Anti-Social Pehavior Change 
PAGE

Analysis of Asocial Behnvior Change

Analys is of Behaviorial Improvement Eatwcen

Agencies

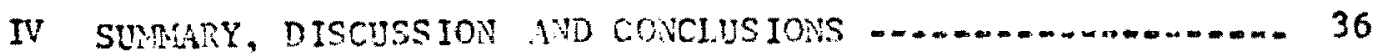

Summary

Discussion

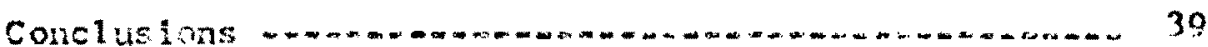

REFERENCES …

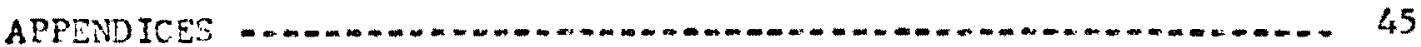




\section{LIST OF TABES}

TABLE

PAGE

I Intra-rater Reliability ................................. 7

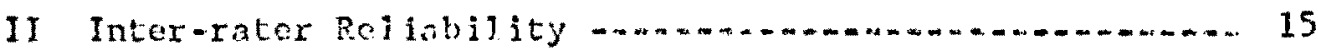

III Suminxy of Analysis of Varlance of Peresptual-Notor

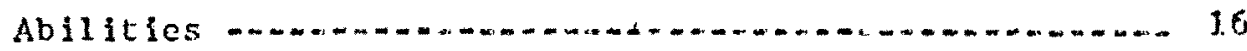

IV Nean Scores For Perceptual Motor Survey ............... 18

V Summary of Anatysis of Vartance of Dohavior Scores ..... 1.9

VI Ilean Scores For Behavior Rating Scale .................. 20

VII Sumbary of Anajysis of Variance of Anti-Social Bonavict

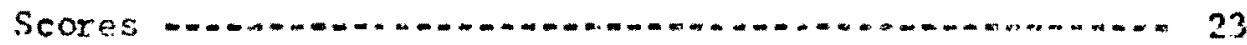

VIII Sican Scotes of Anti-Social Bohavicr Subtest ............ 26

IX Sumnary of Amalys is of Variance of Asocta: Behayior

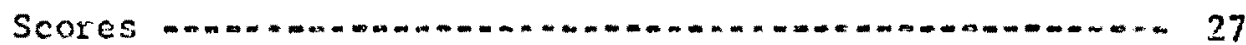

$x$ Mean Scores of The Asocial Behavior Subtest ............ 28

$X I$ Sintrary of Analysis of Variance of Behavior Change Be-

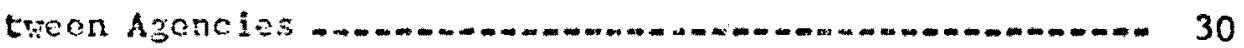

XII Vean Scores For the Behavior Scores of Ageneles ....... 33

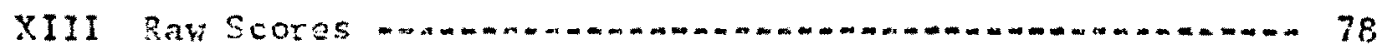




\section{LIST OF FIGURES}

FIGURE

PAGE

1 Treatment Effects over Time 17

2 Treatment and Diagnostic Effects Over Time

3 Treatment Effects Over Tine - 19

4 A Comparison of Withdrawn Experimental and Control Groups on Perceptual-Notor and Behavioral Improvement -...-- 21

5 A Comparison of Acting Out Experimental and Control

Groups on Perceptual-Hotor and Behavioral Improvement - 22

6 Diagnostic Category and Anti-Social Behavior Changes --- 23

7 A Comparison of Withdrawn Experimenta 1 and Control Groups on Perceptual-Motor and Anti-Social Behavior Change

8. A Comparison of Acting Out Experinental and Control Groups on Perceptual-Motor and Anti-Social Behavior Change

9 Treatment and Asocial Behavior Change -

10 Diagnosis and Asocial Behavior Change -

11 A Comparison of Withdrawn Experimental and Control Groups on Perceptual-Motor and Asocial Behavior Change

12 A Comparison of Acting Out Experimental and Control Groups on Perceptual-Motor and Asocial Eehavior Change 
FIGURE

13 Treatment and Behavior Change Over Time

14 Agency and Behavior Change Over Time -

15 Treatrnent, Agency and Behavior Change Over Time --.--- 33

16 A Comparison of Agencies on Perceptual-Motor and Behavioral Improvement -

17 A Comparison of withdrawn subjects on PerceptualMotor Survey -

18 A Comparison of Acting Out Subjects on the PerceptualMotor Survey -

19 A Comparison of Withdrawn Subjects on the Behavior Rating Scale -

20 A Comparison of Acting Out Subjects on the Behavior Rating Scale -

21 A Comparison of Withdrawn Subjects on the Asocial Behavior Subtest 83

22 A Comparison of Acting Out Subjects on the Anti-Social Subtest 
CHAPTER I

INTRODUCTIOH AND THEORETICAL EACKGROUND

The purpose of this study is to detemine whether or not perceptual-notor training has an effect on the maladaptive behaviors of emotionally disturbed children. The largest amount of research on perceptual-motor training has been focused solely on mentally retarded children. Some of this research (Doman, 1960; FcComick, 1968), has shown improved reading and writing skills in the mentally retarded. A number of schools and social service agencies have generalized this success with the retarded to include children with other types of problems. They have adopted perceptual-motor training nethods as treatment for children with learning or behavioral problems. This study was designed to determine whether or not perceptual-motor training is a worthwile treatment to use with children with behavioral problens.

The perceptual-motor training methods chosen for this study were those developed by Radler and Kephart in their book, Success Through Play, (1960). Kephart's methods were chosen because they are the methods most commonly used in clinics, schools and social service agencies today. Some of the locations in which Kephart's methods have been accepted include: Wintarhaven, Florida; Kalanazoo, Michigan; Davenport, Iowa; and Portland, Oregon."

* Very recently there has been an increase in the use of perceptual-motor training methods to prevent the developinent of many learning and behavioral proklems before the child gets into the classroom. In 1966, Portland initiated a preventative program for kindergarten students. The title of the progran was: "Individualizad Perceptua 1-Niotor Study". (Schnckrich, 1967). 
It is likely that Kephart's methods are more commonly used because they are easy to use. These methods may be used for behavioral problems because in his theory of perceptua1-motor development Kephart has related deficient development to social adjustment problems. Kephart feels that many children cannot adequately learn the social skills and adjustments rapidly cnough to meet the expectations of their environment without careful assistance. He states that:

The skills of social adjustment, however, depend upon the more basic skills which allow the child to adjust to concrete objects and things. He must see the same things and it rust elicit the same type of responss before there is a basis for social contact with another individual. (1960).

Kephart's theory of perceptual-motor development is similar to Piaget's in that he uses developmental stages. Kephart vieus perceptua1-motor development as comprising six sequential stages in which the order of the stages was more important than the age at which the stage was reached.

Six general stages are recognized in sequential order:

1) A Gross-Notor Stage; 2) A Motor-Perceptual Stage;

3) A Perceptua1-Notor Stage; 4) A Perceptual Stage;

5) A Perceptual-Conceptual Stage; 6) A Conceptual Stage. They are heirarchiacal, building upon themselves in a related series, although it is recognized that there is some overlapping. Perceptual-motor learning is incomplete If the child's gross-motor learning has been distorted. Likewise, conceptual learning is hindered if areas of gross-motor and perceptual-motor learning have been onitted. (Ebersole, Kephart \& Ebersole, 1968; p. 65).

Kephart (1968) has emphasized early motor learning in all of his research. He places considerable emphasis on early motor learning and on the development of lcarning patterns, rather than the learning of specific motor skills. He states that these early responses are important in the process of learning and development as they become the foundation upon which subsequent learning must be built. He indicates that it is to be expected therefore, that the early response generalizations exhibited by the child sten from motor responses. Kephart believes that because of this early laarning, the 
motor system has developed a certain body of information before the perceptual system begins its development.

Kephart states that specific movements develop out of a generalized pattern of differentiation known as the cephal-caudal and proximodistal trends. This means that the head and trunk regions develop before the lower limbs and that the large muscle groups nearer the center of the body develop before those nearer the extremities. He says that a child must learn to differentiate between his right and left sides and be able to control both, either simultaneously or separately and that the primary method for this is that of being able to balance. Kephart states that 'body image' or kinesthetic awareness of where one is in space and the relationship of himself to other objects must be developed before the concepts of horizontal, vertical, and depth can be developed. He says that visual stimuli are vital in achieving awareness and understanding of these concepts.

Kephart believes that if a child does not go through the developmental stages in the order that he has outlined them, that he may experience some learning and social adjustment failures. These failures could only be effectively negated by corrective perceptual-motor training.

There is 1 ittle research available using perceptual-motor trainIng with emotionally disturbed children. There is less research relating perceptual-motor training to changes in maladaptive behaviors in emotionally disturbed children. There are a few studies which have investigated the perceptual-motor development of these children.

The studies which examined the perceptual-motor development of emotionally disturbed children found these children to deronstrate inadequate functioning in perceptual-motor skil1s; (Llorens, 1964; Berkowitz, 1961; Grass, 1968). These studies used a variety of perceptual-motor tests, but no reference was made to a possible relationship between inadequate perceptual-trotor skills and maladaptive behaviors.

A few studies have been done in which perceptual-motor training was used with emotionally disturbed children. One of these studies was not interested in changes in maladaptive behaviors, but exclusively in 


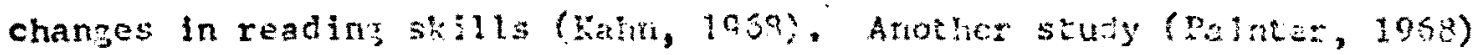
did measure changes in malapt ve behabors, but foum no significant change as a result of tie tratings.

There is a paucity of research in wich pexcegtud-notor trainlng was used with ehlliren vith tehavior roblers. Thexe is virturliy no resesroh that supports kepherts theneles of perceptual -Totor devel-

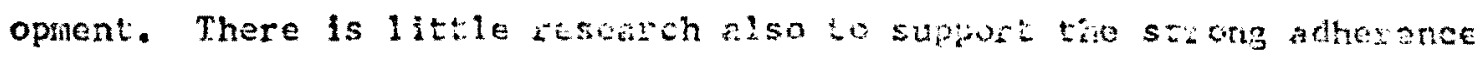

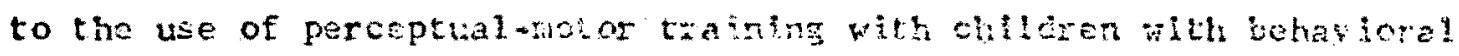
or enotional problems. Thexs is a demand for roweresech in this

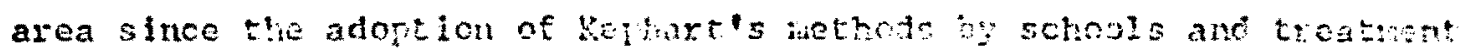

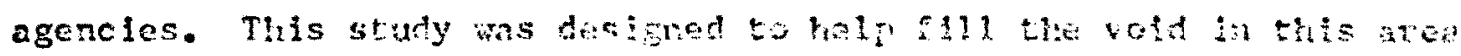

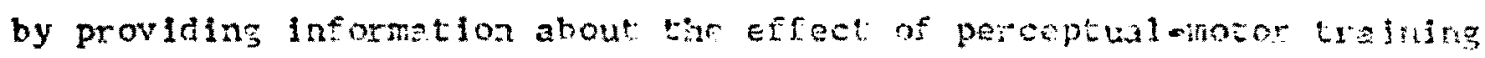
on maladapilve behoviors of enotisully ciatribed chlidrou. 


\section{SAMPLING AND ASSTSMENT}

Three agencies dealing with emotionally disturbed children in the Portland metroplitar arca contained the population from which the sample of twenty emotionally disturbed children was chosen for the study. One agency was a public school with two classrooms of emotion. ally disturbed children. They used behavior modification lechuigues for dealing with the childrens' learning and behavioral problens. Another agency was a semi-res!dental treatment center which uses a combination of behavior modifination techniques and milieu therspy. A system of small classes on campus is used for school. The children 1 ive on the campus during the week and go home for the weekends. Ail of the childrens' families recelve some counseling at the certcr. Mise third agency was a residential center which uses a total miliou therapy where some of the chlldren return home for an occasional visit and some of the families receive counseling at the center. Teachers cone to the agency and work with one or two of these children at a time. The children were chosen for the study on the basis that they were at least six years old and no more than thelve years old and that they were not prosently enrolled in a perceptual-motor training prozian.

The subjects were matched in pairs according to their ages and clinleal diagnoses. One half of each pair was randomly chosen to be a part of the experimental group by the toss of a coln. The other halves of the pairs vere placed in the contral group. In order to obcain more meaningful results in analys is the subjects were categorized i-to two major diaznostle groups, withdrawn and acting out. The withdrawn group included chllden with thought disoiders such as childhood schizophrenia and autish is we!l as childzen diagnossd ony as withdrain. The actlng out group haluded chllden with a diagnes!s of 'anxiety reaction to chlldund' ard all types of acing out publems. 
After the children had been assigned to either the experimental or the control group and to either the withdrawn or acting out group there were five withdrawn and five acting out children in both experimental and control groups. Half of the children from each agency had been placed in the experimental group and the other half placed in the control group.

The experimental subjects were listed alphabetically and then numbered consecutively. Experimenter I was assigned subjects 1, 2, 3 , and 4 and their matched pairs in the control group. Experimenter II was assigned to subjects 5 and 6 and their matched pairs. Experimenters III and IV were assigned to sub jects 7, 8, 9, and 10 consecutively and their matched pairs in the control group. Each experimenter was assigned half experimental subjects and half control subjects in order to better insure that. any significant difference between the experimental and control groups on behavior or perceptualmotor ability change was due to the treatment rather than the experimenter.

\section{TESTING AND RATING PROCEDURES}

All of the subjects were administered the Purdue Perceptual-Motor Survey designed by Roach and Kephart (Appendix A). Roach and Kephart estimated the reliability of this measure with a coefficient of stability which was 94 . Each of the test items are scored according to Kephart's system. Each child obtained a score from 1 to 4 on each of. the test items. A 4 indicates a competent performance and a 1 generally indicates that the child cannot perform the task. Each child obtained a total raw score which had a possible range of 22 to 88 (Appendix C).

Each subject had 2 behavior rating scale filled out on him by three adults who worked closely with him (Appendix E). The raters were teachers, teacher aides and child care workers. The raters were unaware of which children would receive training and which would nat receive training. 
Reliability of The Belgyior Rating Seale

The intra-rater feliabilizy was tested at a fourtin agency, (Parry Center For Children). for emotionally disturbed children in the Portland metropolitan arca. A coeffleient of stability was used to estimate the intra-rater reliablity. Three child care verkers were asked to rate four children on the behavlor scale and five days later they werc asted to rate the same four chlldzeulagain. The test-retest reliablity test using the parson 7 vas used to obtain the coefficient and vas found to be significant at .01 for all of the correlations.

TABLE I

INTRA-RATER RELIAR IZITY

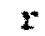

\begin{tabular}{|rc|}
\hline & \multicolumn{1}{|c|}{} \\
\hline Rater I & .886 \\
Chlld 1 & .529 \\
Child 2 & .552 \\
Child 3 & .857 \\
\hline Rater II & \\
Child 1 & .808 \\
Child 2 & .639 \\
Child 3 & .864 \\
Child 4 & .628 \\
\hline Rater III & \\
Child 1 & .822 \\
Child 2 & .683 \\
Child 3 & .937 \\
Child 4 & .856 \\
\hline
\end{tabular}


The behaviors were rated according to how much the adult had noticed the presence of each behavior in the child. If the child displayed the behavior very often or more than once a day that behavior obtained a rating of 5 . If the behavior had never been noticed, the behavior rating was 1 . There were thirty maladaptive behaviors described in the scale. Each child obtained a total raw score on the scale which could range from 30 to 150 for each rater. These scores of the three raters were averaged to obtain an average total behavior score. Each child also received an anti-social subscore (Appendix F) obtained from five of the behaviors described and an asocial subscore (Appendix $G$ ) obtained from another five behavior items. The subscores were developed in order to make a scale more sensitive to behavioral changes among withdrawn children by differentiating the behaviors that are typical of withdrawn children (asocial behavioral) from those which are atypical (anti-social behaviors).

Validity of The Behavior Sub-scales

The face validity of the subtests in the behavioral scale was established by having two persons, other than the primary experimenter who were familiar with disturbed children categorize all of the behaviors in the behavior scale into either anti-social behaviors or asocial behaviors. Two child care workers who were not to be involved in the study were chosen for this task. There was total agreement among the two workers and the primary experimenter on al1 the items chosen for the two subtests. 
IIL. TRAINING PROCEDURES FOR EXPERDMENTAL SUBJECTS

The experimental subjects received perceptual-motor training as defined by Kephart and Radier in their book, Success Through Play, (1960), for one half hour, three times a week for nine weeks. The length of the study, nine weeks, was chosen so that if the method is effective, it can then be used in conjunction with a nine week: grading period in a school program.

Each experimental child received training in each of the six main areas during each week. His accomplishment of each step in the following tasks is recorded on a progress chart (Appendix $H$ ). When he can competently perform a task on a regular basis, the date of accomplishment is recorded. A record is also kept of how much time is spent on each activity every day (Appendix I).

Ange 1s-In-The-Snow

The child lies flat on his back on the floor with his feet together and his arms to his sides. First he is asked to move his arms until his hands meet above his head, keeping his elbows straight. He is encouraged to push his heels against the floor as he moves his legs and to press his hands against. the floor as he noves his arms. He is also encouraged to click his heels as his feet come together and to slap his sides with his hands as he brings them back down. Initially the child can be helped by moving an arm or leg for him until he can complete the movement on his own. Once the child has learned these movements, the trainer may have him combine leg and arm movements. His heels should click at the sane time that his hands slap his legs. The next step is to have the child move only his right leg, only his left leg, etc. If the child has difficulty holding the other limb still, the trainer may hold the other limb for hirn, until he can accomplish the task by hinself. The child may have aid in indentification of 2 limb by touch until he is able to identify the part by pointing alone. After the chlld has mastered single limb control, he is asked to move his right leg and right arm together 
and then his left $1 \mathrm{eg}$ and left arm. When this is accomplished, cross-lateral movements are requested, such as left leg-right arm, and vice versa. When the afore mentioned tasks have been mastered, the child is asked to do the tasks in rhythrn counting. When this is accomplished, the child is asked to repeat the same tasks while on his stomach with a pillow placed under his abdomen.

Walking Board

The child is first asked to start at one end of the board and walk slowly to the other end. Initially the trainer may aid the child by holding his hand. It is essential that the child walk slowly and that each foot be placed squarely on the board so that toe and heel make contact on each step. After the child has learned to walk the board forward, he learns to walk it backwards. Initially the child is allowed to look back to see where he is going but must learn to master the task without looking. Next the child learns to walk the board sideways. He begins by standing on the left hand end of the board and beginning with his preferred foot, steps out, shifts his weight, and moves his other foot until his feet are together. This sequence is repeated until he has crossed the board. Then he returns to the starting point with the sequence of actions reversed, leading with the other (non-preferred) foot. When the child has accomplished these three tasks and balance. is maintained, he is taught to turn on the board. He is asked to walk forward across the board, and without stepping off, turn and walk sideways back. When he has accomplished this half turn, he is asked to walk forward across and return walking forward, making a full turn. Finally he is asked to walk backward across the board, make 2 full turn, and to return walking backwards.

Balance Board

(See Appendix D) The child starts with the five inch balance board and when he can balance without difficulty, he practices balancing on the four inch board. When this is mastered, he practices balancing on the three inch board. When the child has accomplished this task, he is asked to bounce a ball while balancing. The child begins with 
2. 1arge (basketta11) bal1 and decreases to a smal1 (tennis) ball. He bounces the ball with both hands, then only the preferred hand, and then the other hand. While balancing on the board, the child is then requested to play catch with the trainer. When this is accomplished, the child is asked to perforin his Marsden ball tasks (see page 12) while maintaining his balance on the three inch board.

\section{Drawing Games}

First the child is asked to trace with his fingers a drawing of a circle that the trainer has put on the chalkboard. When this is easily performed, the child is asked to draw a circle. The trainer may guide his hand to aid in closure. The circle must be drawn across the midline and starting at the top, proceed counterclockwise if his right hand is preferred, or clockwise if the left hand is preferred. Next the child must be able to reproduce 2 straight vertical line, beginning by copying a line by the trainer. When the vertical line can be drawn without aid, the child may progress to horizontal lines in the same manner as the vertical. The horizontal line must cross the midline of the body. Next the diagonal line is introduced by asking the child to copy a triangle and then a diamond. When the straight 1 ine tasks have been nastered, the child is asked to participate in a game of following dots. The trainer places two dots on the chalkboard and the child draws 2 straight line from one to the other. When this is accomplished without overshooting the dots, more dots are added, one at a time at random. The child is asked to move from one dot to the next without lif.ting his chalk. When the child has successfully achieved this, the dots may be placed to make meaningful designs.

\section{Pegboard}

First the child is asked to copy a straight vertical row of pegs, then a straight horizontal row, and then a diagonal row. Next the trainer outlines a simple figure such as a square, triangle, 
etc. and the child is asked to make one like it on his board. He may look at the form during the entire time that he is constructing his copy. Initially the child may be aided by a cardboard template in the shape of the form presented as a guide. When the child can construct simple forms, more complex forms such as a house or boat are introduced. Also specific color patterns are introduced on the simple forms and later the nore complex forms.

\section{Marsden Ba11}

The child stands arms iength from the ball with the pivot line of the string directly in front of him. The trainer pulls the ball to one side and releases it, letting it swing across in front of the child. The child is asked to reach out and touch the ball as it passes in front of him. He is not allowed to obstruct the path of the bal1. At first the child must begin by holding his hand by his shoulder and thrust out to touch the ba11, then he begins at a point by his eyes, and then from the hip. He must thrust in one steady movement and keep his head still, facing forward, but follow the ball with his eyes. This task begins with a small arc and increases to a larger arc of swing. Once he can do this, the child is instructed to thrust only when the trainer says 'now'. When the child has mastered this task as the ball swings laterally, he is asked to perform the same task as the ball swings forward and back. On this task the child touches the ball from underneath. He should hit the ball squarely from underneath. When this task has been accomplished, the child may be given a short bat with which to bunt the ba11. For this task, the child is asked to reach out and meet the ball, rather than waiting for the ball to hit the bat. When all Marsden ball tasks have been mastered, they may be attempted from the balance boards.

The tasks involved in the training are meant to improve coordination, balance, and left and right differentiation. Kephart feels that no single task can be used singularly for this improvement, it is necessary to use 211 of the tasks. 


\section{PKOCEDURES GOR COYTROL SUPJECTS}

The control subjects recelyed individual attention for one half hour, three times a veek for nine veoks. The time spent with the cortrol group included physical activities, (physical games and zeneral playground play), and quiet activities (checkers, puzzles, ete.). Ail of the experimenters attemptes to put equal emphasis on both the physical and quiet activitjes as often as poselble. An activity record was kept for each child recordin whet type of activity was participated in during each session (Appendix J).

\section{RE-TESTING AND RATING}

At the end of the nine veeks of individual attention or craining all of the subjects were adninistered the Purdue Perceptual-iotor Survey again to deternine the amount of increase in perceptual-Intor ability. One subjcct from the withdrawn control group was released fron are at one of the agencles and vas not evailable for testing. The adults who rated the subjects' behavior at the beginning of the stully were again asked to fill out the behavior rating scale on each child. Behavior ratings were obtained on all twenty subjects in the study.

\section{HYPOTHESES}

Based on research using perceptual-notor training cited earlier, it vas predicted that subjects in the experimantal group nould show more improvement in perceptual-motor abilities than subjects in the control group. Research cited in Chapter I demonstrated that one effect of pereptual-motor training with retarded children was that the ir social adjustment improved. On the basis of that effect, it vas predicted that the maladaptive behaviors of the experimontal subjects rould decrease more than the maladaptive behaviors of the control subjects. It was piedjeted that the vithdrawn subjects would inprove more in perceptual motor ahilities than acting out subjects 
because the witlowirn subjects vere far below their age level in percentual-motor ablities and sesmed to need the training, whoreas, the acting out subjects verc, on the averase, nt age level. It vas also predicted that the withdran subjects who recelved the training would inprove more bolavionally than acting out subjects tho received the trainins.

It was felt that the training rould help the vithdrayn subjects to be nore aware of thenselves in relationship to their environment: by forcing then to attend to the movement and control of the it 1 imhs. If there is nore awereness aliong these subjects as a result of the training, they may spend less tine hallucinating. Since asoctal behaviors, rather than anti-social are predoninate anong withdram childen and the withdratu children have been predicted to inprove the most, it ras also predicted that the asocial behaviors on tha average vould shon gronter change over tine than rould the arti-soclal behaviors. 
CHAPTER III

RESULTS

\section{REI.IABILITY OF THE BEHAVIOR RATING SCALE}

The Inter-rater reliability of the behavior scale was determined from the scores of three raters' ratings of elght chlldren who participated in the study. Raters I and II were teachers and rater III was a teacher's alde. The raters vere given no other instructions than those present on the form of the behavior rating scale (Appendix E). The scores of Rater I vere correlated with those of Rater II to yleld a coefficlent of .846 . Rater I scores were correlated with Rater III scores ylelding a coefficient of .500 and scores of Rater. II correlated with those of Rater III gave a coeficient of .583 . A t-test was conducted showing only one of the coefflclents to be slgniflcant at .05. The other two coefflcients were significant at .10. The results of these tests are shown in Table II.

TABLE II

INTER -RATER REL IABIL ITY

\begin{tabular}{|c|c|c|}
\hline & $r$ & $t$ \\
\hline Raters I and II & .846 & $2.449 \%$ \\
\hline Raters I and III & .500 & 1.413 \\
\hline Rat?rs II and III & .583 & 1.758 \\
\hline$P<.05$ & & \\
\hline
\end{tabular}


Since each child 's behavior score was the mean of his three ratings by the raters, the rellability of using the average of the three raters was flgured. Using the Spearman-Brown prediction formula a coefficient of .867 was determined. This formula is similar to the Spearman-Brown Prophecy formula in that, rellability for the measure Increases as the number of raters increases.

\section{ANALYSES}

An analysis of variance for a three factor design with repeated measures was used to determine the effectiveness of the treatment in improving perceptual-motor abilities and behavior.

\section{Analys is of Perceptual aMotor Change}

An analysis of variance vas computed on the perceptual-motor scores and significant differences were found between groups and over time. The sumnary of the anaiysis shown in Table III demonstrated that

TABLE III

SUNMARY OF ANALYSIS OF VAR IANCE OF PERCEPTUAL - MOTOR ABIL ITIES

\begin{tabular}{|c|c|c|c|c|}
\hline SOURCE & SS & de & $\because s$ & $F$ \\
\hline Betwoon Subjects & $7,489.128$ & 37 & & \\
\hline $\begin{array}{l}\text { A (Treatment) } \\
B \text { (Dlagnosis) } \\
A B \\
\text { Between Subj. Error }\end{array}$ & $\begin{array}{r}868.147 \\
1,289.504 \\
182.371 \\
5,149.400\end{array}$ & $\begin{array}{r}1 \\
1 \\
1 \\
34\end{array}$ & $\begin{array}{r}868.147 \\
1,298.504 \\
182.371 \\
155.580\end{array}$ & $\begin{array}{l}5.072^{*} \\
8.514 \div \div \\
1.204\end{array}$ \\
\hline Within Subjects & $2,029,576$ & 38 & & \\
\hline $\begin{array}{l}C \text { (pre and post test) } \\
A C \\
B C \\
A B C \\
\text { With in Subj. Error }\end{array}$ & $\begin{array}{r}1,078.495 \\
373.503 \\
15.920 \\
267.057 \\
294.600\end{array}$ & $\begin{array}{r}1 \\
1 \\
1 \\
1 \\
34\end{array}$ & $\begin{array}{r}1,078.496 \\
373.503 \\
15.920 \\
267.057 \\
8.665\end{array}$ & $\begin{array}{c}124.470 \% \\
43.106 \% \\
1.837 \\
30.714 \%\end{array}$ \\
\hline Tota 1 & $9,518.698$ & 75 & & \\
\hline
\end{tabular}


there were significant differences between the treatment groups and the diagnostic groups. The treatinent difference was significant at .05 . The difference between the two diagnostic groups was significcant at .01 . The analysis showed that the perceptual-motor abilities of the subjects increased over time, which was also significant at .01 . There was significant interaction between treatment and change in perceptual-motor abilities over time. An $\bar{F}$ test was performed on this and found to be significant at .01 , as seen in Figure 1 . There
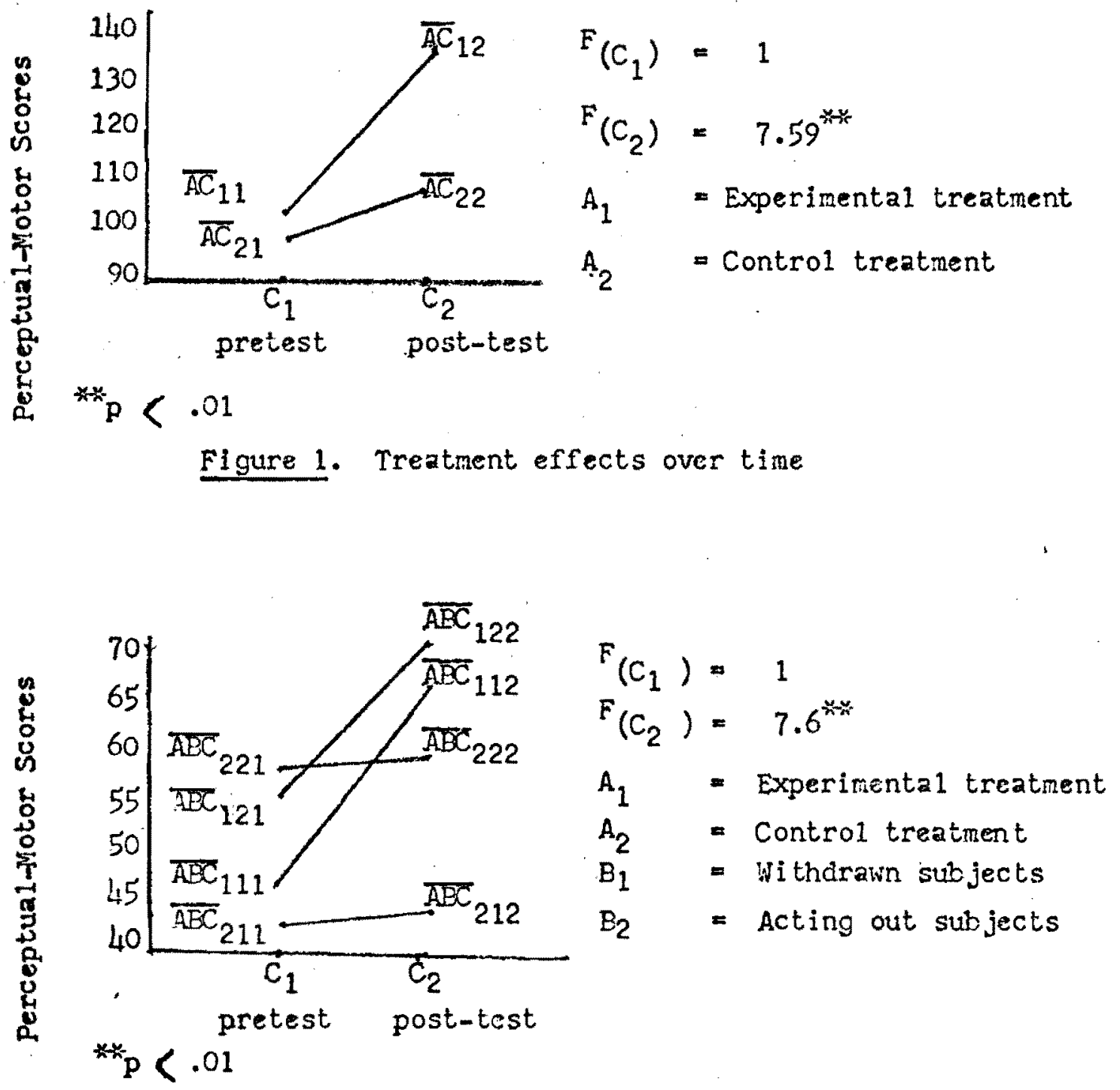

Figure 2. Treatment and diagnostic effects over time 
was significant interaction between the treatment, diagnostic category and perceptual-motor change over time as seen in Figure 2. It was also found to be significant at . 01 .

The experimental subjects who were in the withdrawn diagnostic category made significantly more improvement in perceptual-motor abilities than any other group. This is easily seen fron the figures in Table IV. The withdrawn subjects scored lower than the acting out subjects on the perceptual-motor test prior to the training; however, following training the withdrawn experimental subjects scored higher than the acting out control subjects.

TABLE IV

MEAN SCORES FOR PERCEPTUAL-MOTOR SURVEY

\begin{tabular}{llll} 
& Pre & Post & Total \\
\hline EXPERIMENTAL & & & \\
Withdrawn & 45.0 & 67.0 & 112.0 \\
Acting out & 55.6 & 71.0 & 126.6 \\
\hline CONTROL & & & \\
Withdrawn & $41.0^{*}$ & $43.0^{*}$ & $84.0^{*}$ \\
Acting out & 56.4 & 59.8 & 116.2 \\
\hline TOTAL & 198.0 & 240.8 & 438.8 \\
* figured from 4 scores. & &
\end{tabular}

Analysis of Behavioral Change

The analysis of variance on the total behavioral scores show a. significant change in behavior over time. The amount of behavior change was significant at .01. A summary of the analysis is shown in Table $V$. The analysis also pointed out that the amount of behavior change was closely related to the condition (experimental or contro1), in which the subjects had been placed. This relationship which was significant $2 t .01$, is demonstrated in Figure 3. 
TABLE V

SUMAARY OF ANRYSIS OF VAR IANCE OF

TOTAL BEHAVIOR SCORES

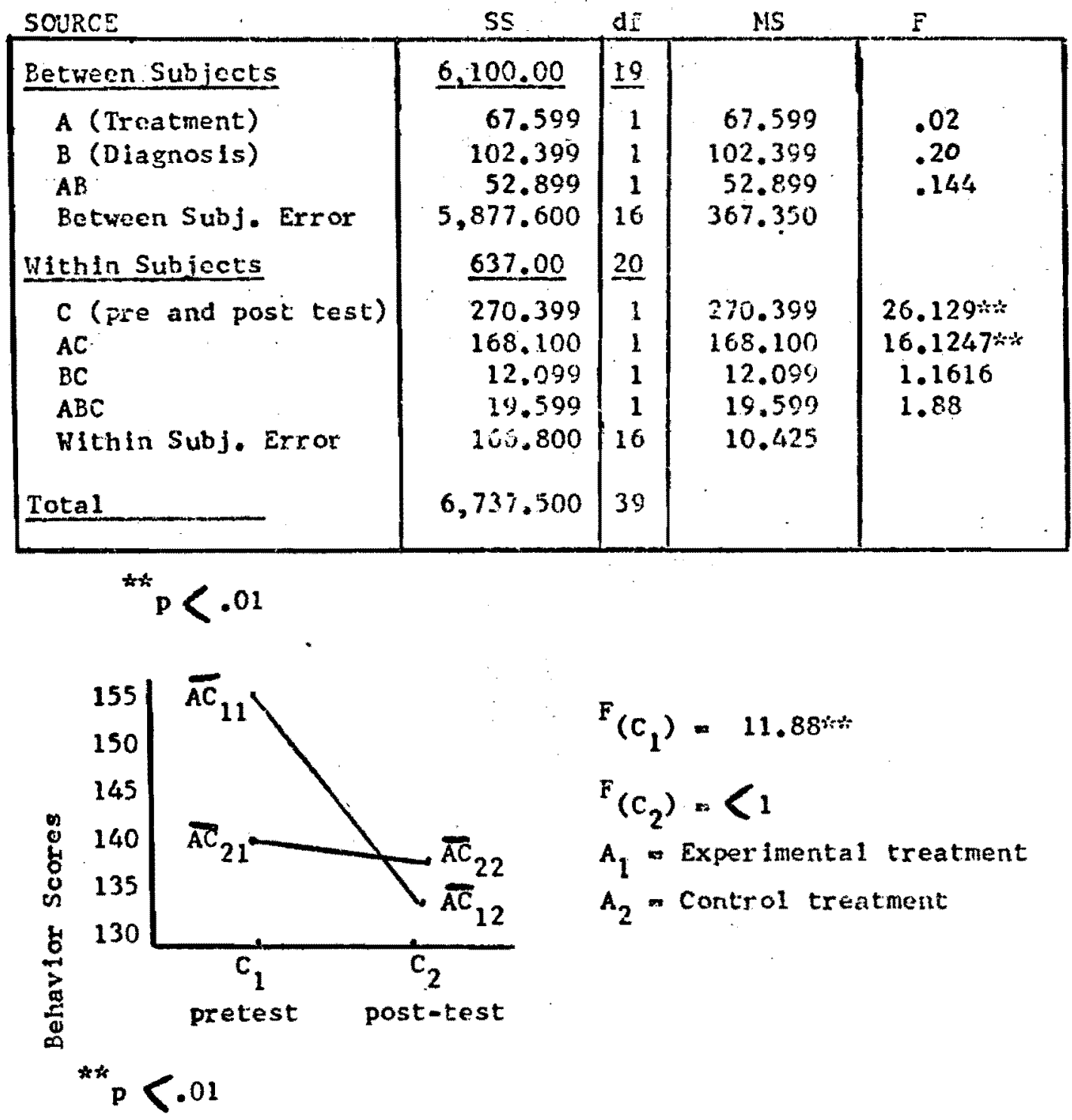

Figure 3. Treatment effects over time 
The experimental subjects who vere in the withuram diagnostic category made moxe improvement behavioraliy than any of the other groups. This is apperent froin the glgures in Table VI. The withdrawn subjects were generally seen by the raters as more maladaptive than the acting out subjects prior to the treatment, and about the same as the acting out subjects after treatment.

TABLE VI

MEAN SCORES FOR THE BEHLVIOR RATING SCALE

Pre

Post Total

\begin{tabular}{llll} 
& Pre & Post & Total \\
\hline EXPER INENTAL & & & \\
Withdrawn & 77.0 & 65.2 & 142.2 \\
Acting out & 75.4 & 63.6 & 144.0 \\
\hline CONTROL & & & \\
Withdrawn & 66.6 & 65.8 & 132.4 \\
Acting out & 72.4 & 71.0 & 143.4 \\
\hline TOTAL & 291.4 & 270.6 & 561.0
\end{tabular}

Graph's (Figures 4 and 5), were made to compare the change in perceptual-motor abllitles with change in behavior for all four of the groups. Nearly all of the subjects improved in perceptual-motor abilities. Most of the subjects inproved in behavior also, but to a smaller degree. The perceptuel-motor training appeared generally to effect behavlor change which was to decrease maladaptive behaviors in the chiluren, especlally the withdrawn children.

Analys is of Anti-Soclal Behavior Change

An analys is of the antl-soclal behavior subscores showed a significant difference between the diagiostic groups, as was predicte. This difference was significant at .01 . The summary of this analysis is shown in Table vII. Figure 6 shows the relationship of the diagnostlc categories to the change in anti-soclal behaviors over time. This relationship was significant at .05. 


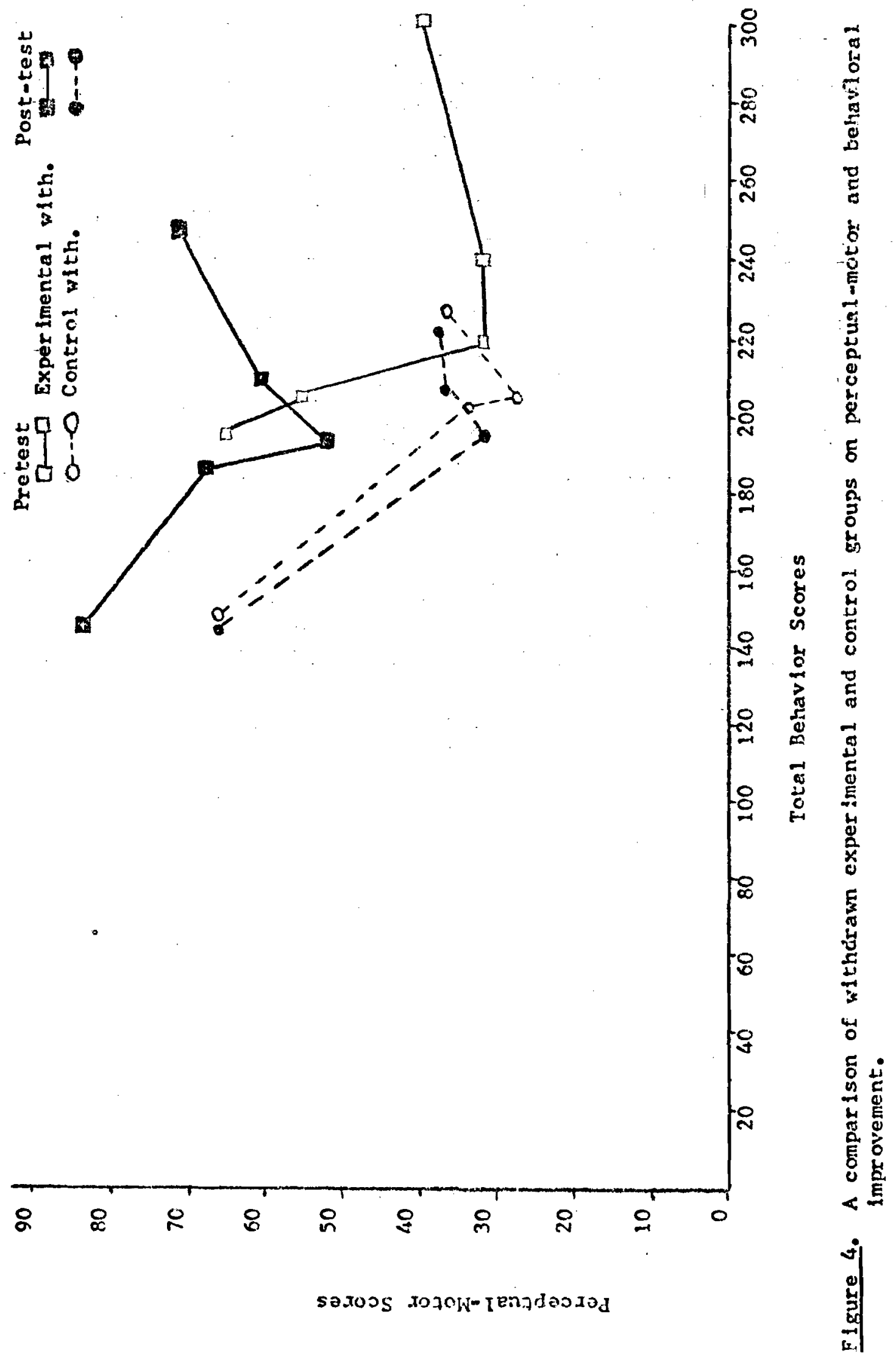




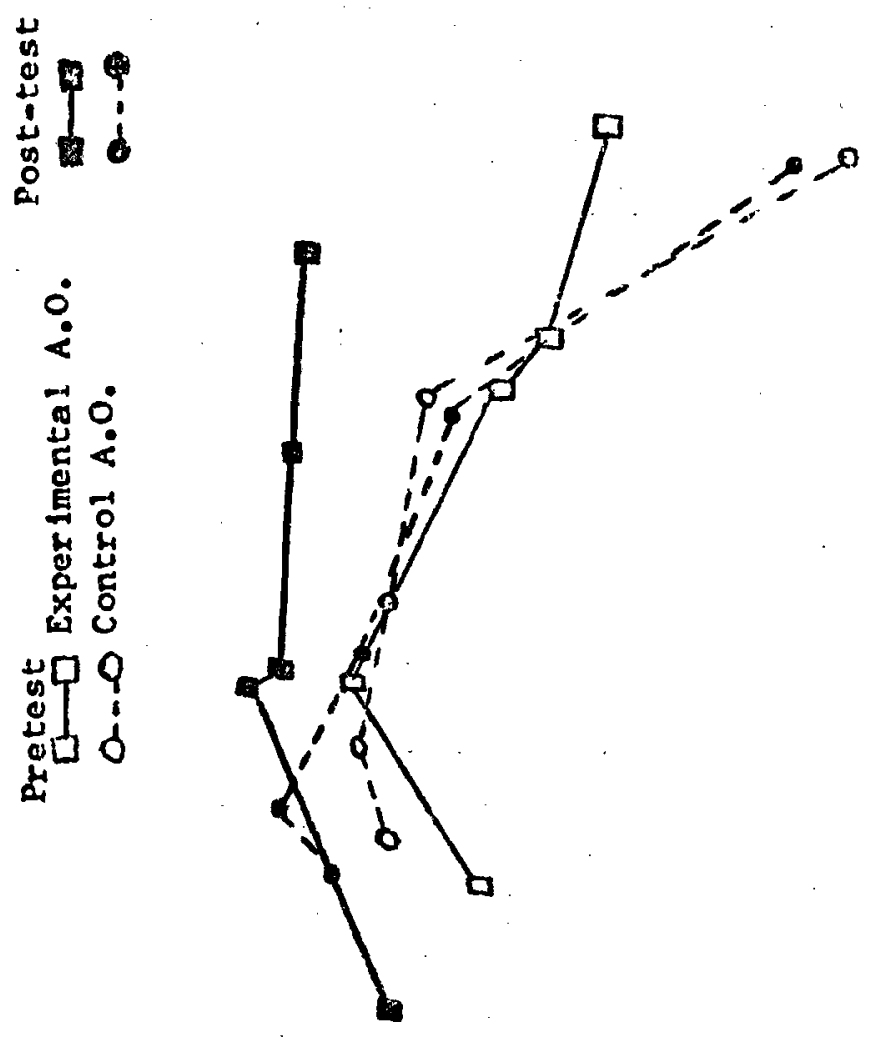

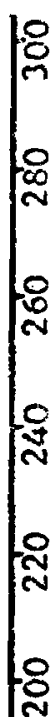

है

$\infty$

递

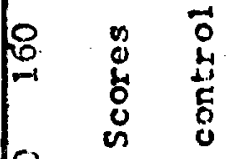

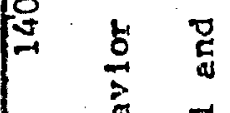

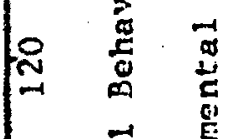

용 章

10

苛

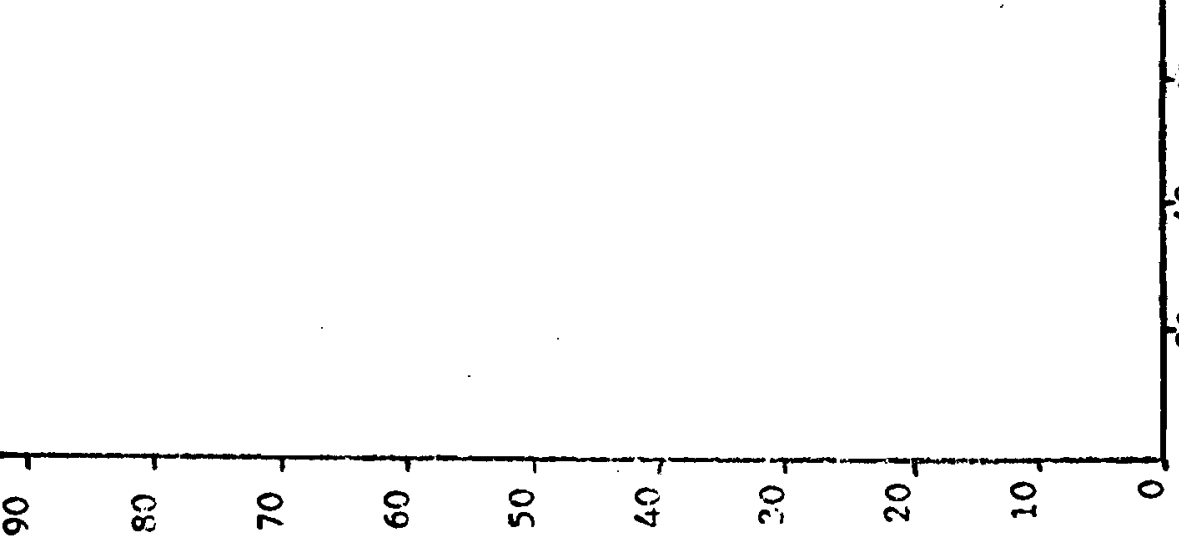

18

䒺

9

오

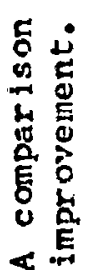

굴 
TABLE VII

SUMGARY OF ANALYSIS OF VAR IANCE OF ANTI-SOCIAL SWHAV IOR SCORES

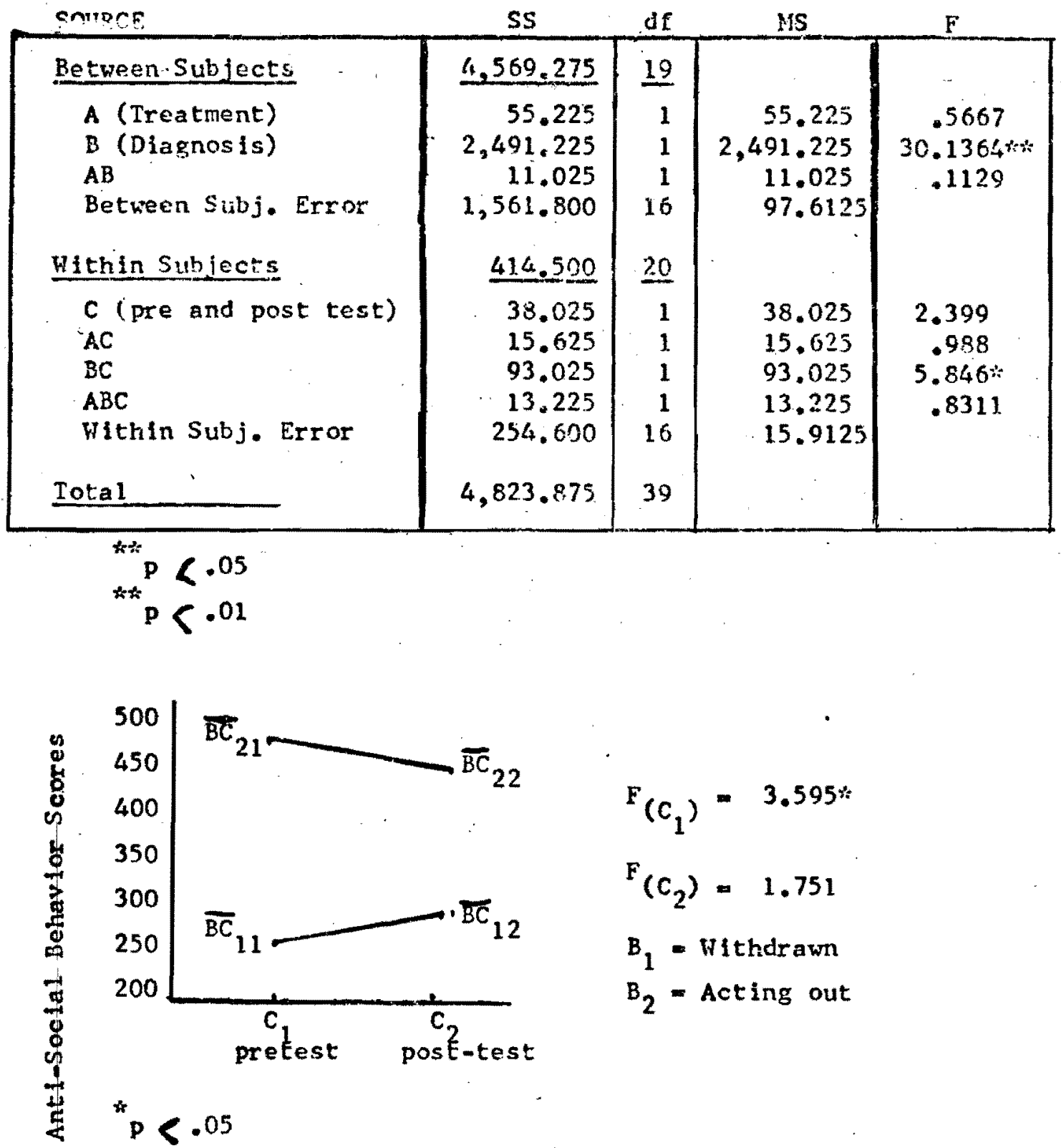

Flgure 6. Dlagnostic category and antl-social behavior changes 

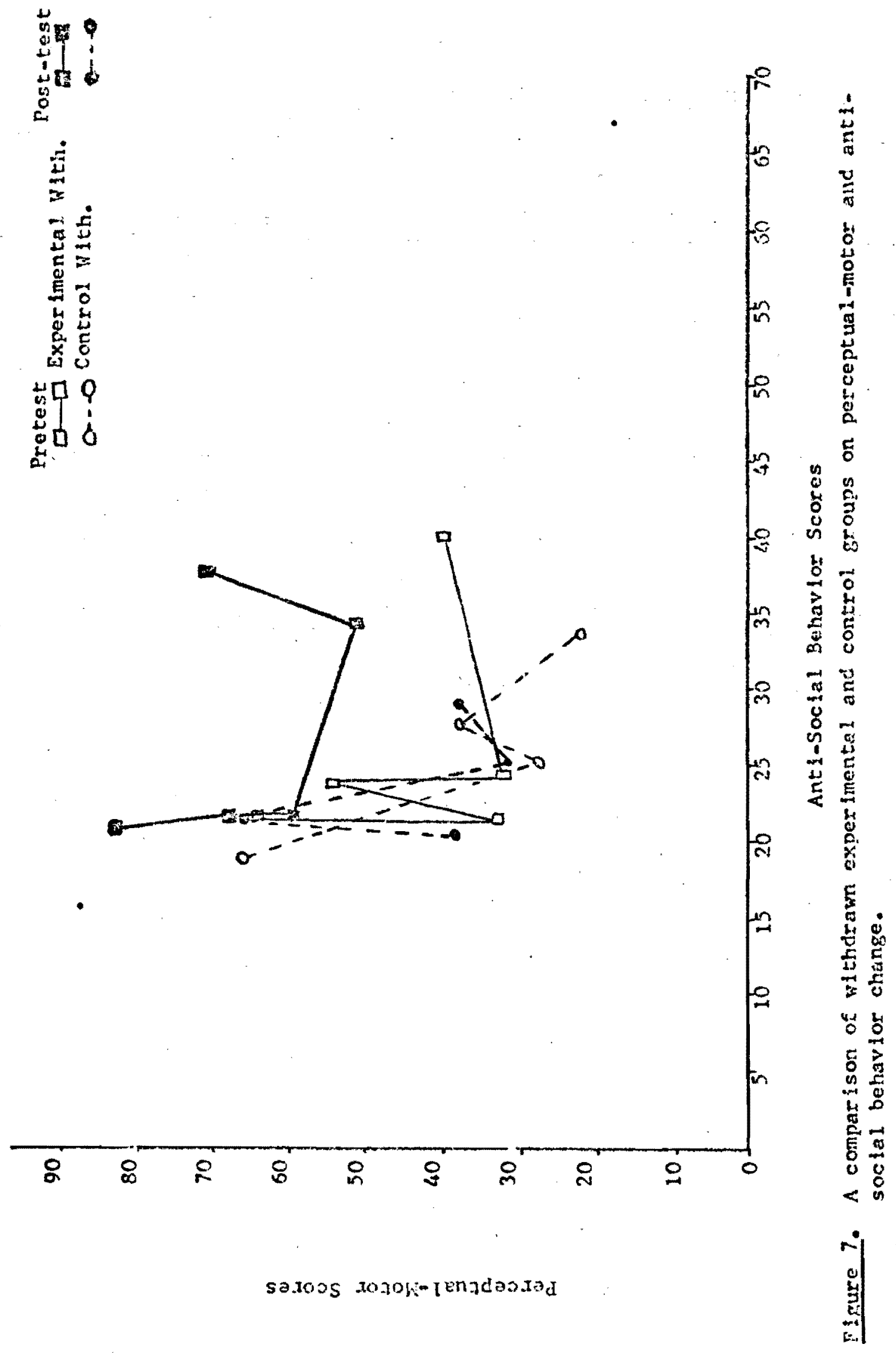

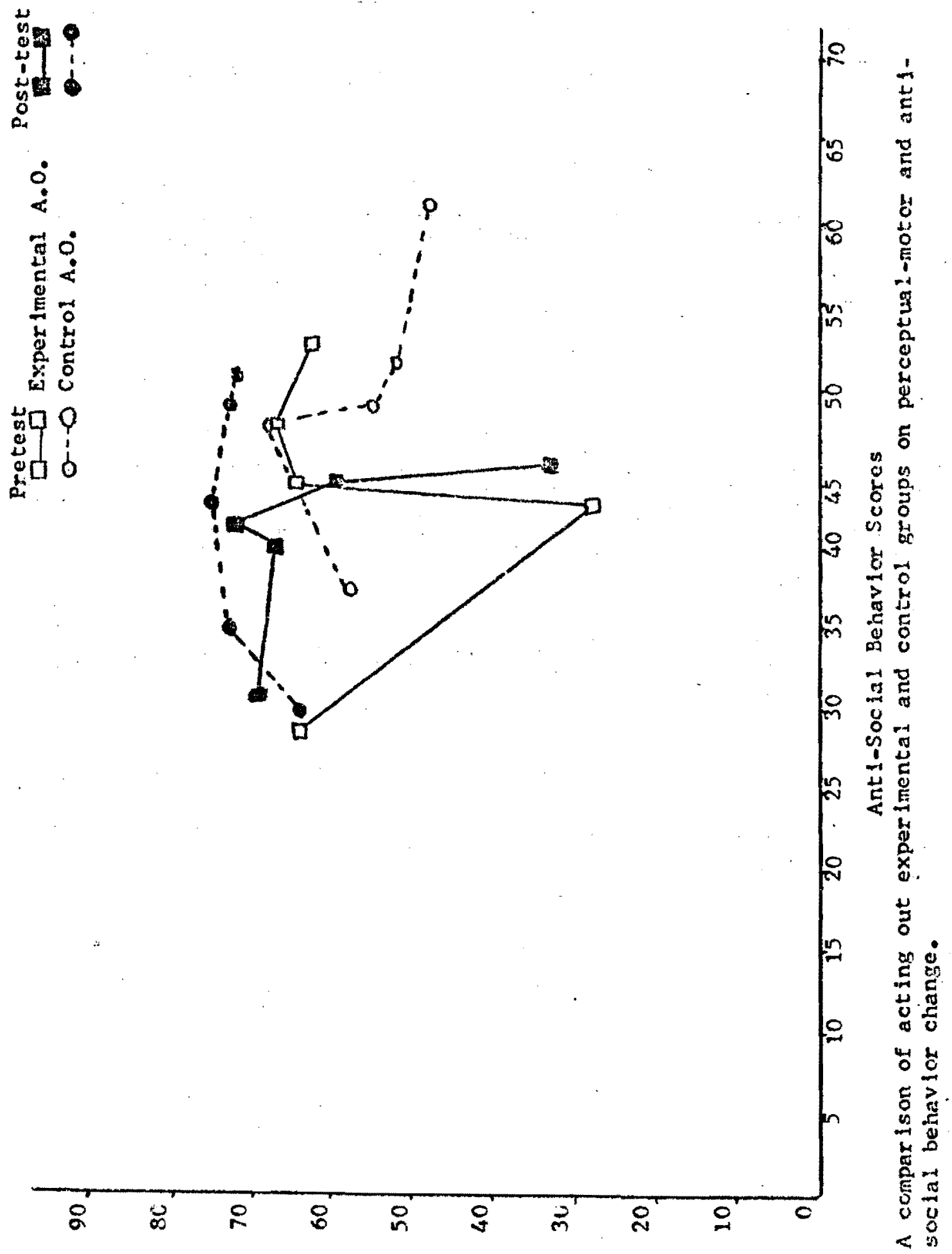

Sodoss $207014-1$ rnjdisosad 
As the acting out subjects improvid behavlozally, the ir ant 1social scores decreased, and as the withdrawi subjects improved their anti-social scores tended to increase. This relationship can be seen in Figures $i$ and 8 . As the perceptual-mocor abilities increased the anti-social scores of the acting eut subjects decreased. As the perceptual-motor abllities Incrased for withdram subjects, there was very little change overall in ahtl-soclal behavior.

It was interesting to note that the treatment didn't seem to effect very much improvement in antl-social behaviors except for the experimental acting out group. The withdrawn children who were in the control group displayed more improvement here than did the experimental withdrawn. This relationshlp can be seen in lable VIII.

\section{TABI,E VIII}

MEAN SCCRES OF THE ANTI-SOCIAL BEHAVIOR SUBTEST

\begin{tabular}{llll} 
& Pre & Post & Total \\
\hline EXPER IMENTAL & & & \\
Hithdrawn & 25.4 & 27.4 & 53.8 \\
Acting out & 48.8 & 41.4 & 90.2 \\
\hline CONTROL & 5 & & \\
Withdrawn & 25.0 & 26.2 & 51.2 \\
Acting out & 43.0 & 40.4 & 83.4 \\
\hline TOTAL & 143.2 & 135.4 & 278.6
\end{tabular}

\section{Analys is of Asoclal Beliavior Change}

An analysis of asocial behavior change revealed many significant differences. There was a difference between the dlagnostic groups significant at .01. There was a significant change in asocial behavlots over time and this was also slgnificant at .01. The sumary of the analysis in Table IX indicates several interaction effects. The treatment condition affected the amount of improvement In asoclal behavior. This relat ionsilip can be scen in Figure 9; it was signiflcant at .01. The diagnostic category had a greater effect 
TABLE IX

SURATPY OF AVALYSIS OE VAR IANCE OF

ASOCIAL BEILVIOR SCORLS

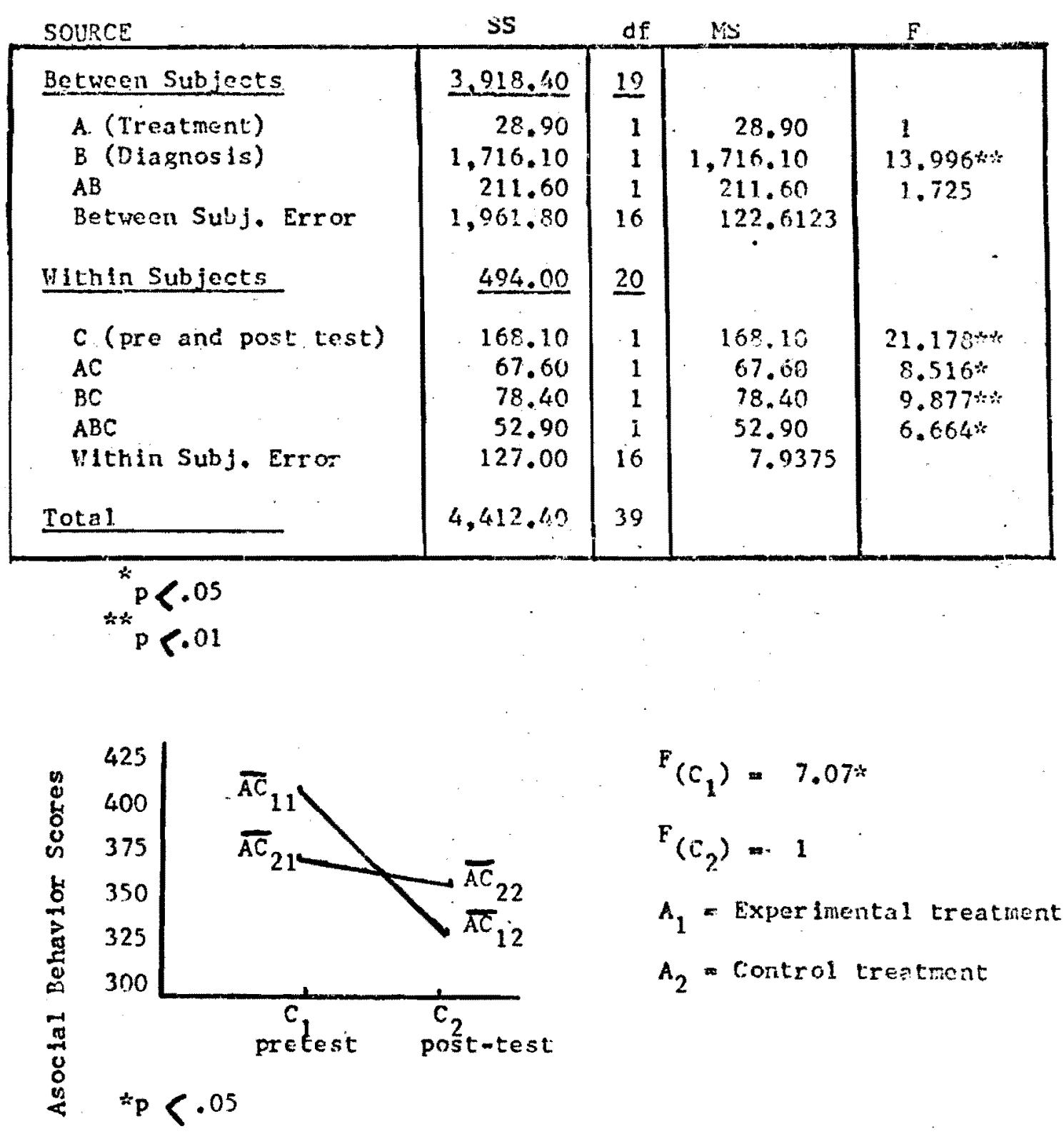

Flgure 9. Treatment and ascclal behavior change. 
on asocial behavior change than treatment. As is shown in Figure 10 , this relationship fas significant at .01. This effect was to be expected because the vithdrawn subjecrs would have larger asocial scores than the acting out subjects. For the first time in all of

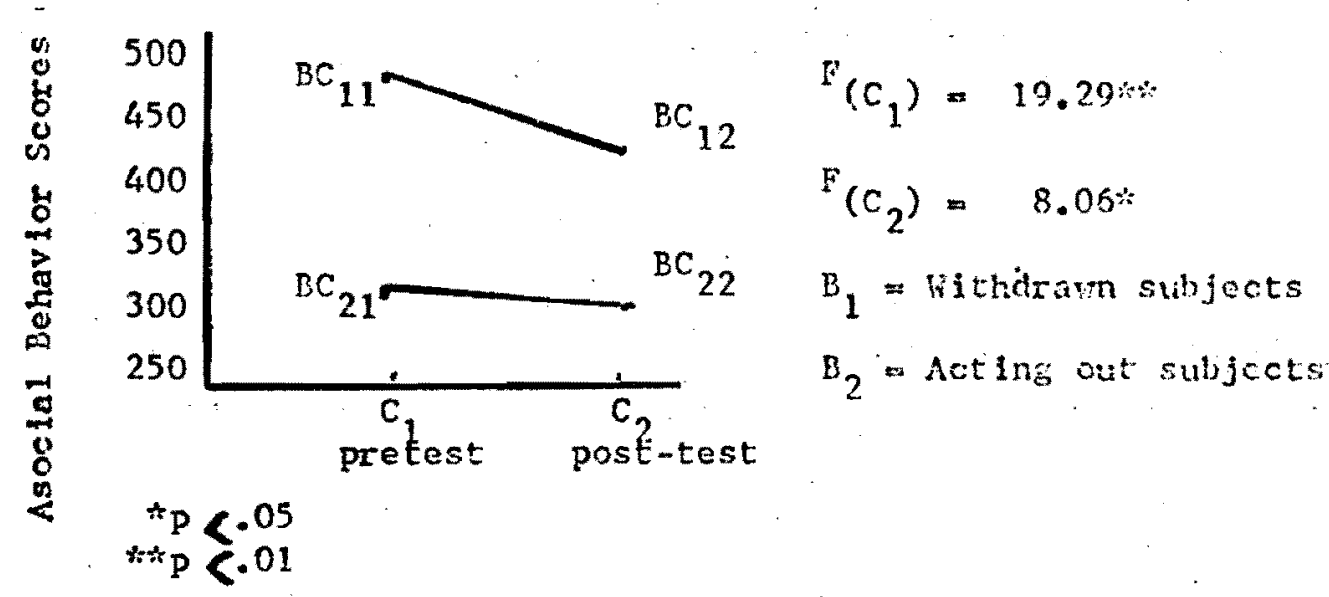

Figure 10. Dlagnos is and asocial behavior change.

the analyses, a combined effect of treatment and diagnosis is evident. There was a definite relationship betresn the treatment condition, dlagnostic category and the amount of improven:ut in asocial bohavlors over time. This relationship significant at .05, is illustrated in Figure 11. Table $X$ shows that the withdram children in the expertmental group improved signiflcantly, but there was little charge in the other three groups.

TABLE X

MEAN SCORES OF THE ASOCIAL BEHAVIOR SUBTEST

\begin{tabular}{llll} 
& Pre & Post & Total \\
\hline EXPER MENTAL & & & \\
Nithdrawn & 51.4 & 39.6 & 91.0 \\
Acting out & 28.6 & 27.0 & 55.6 \\
\hline CONTROL & & & \\
Vitingan & 40.2 & 33.2 & 75.4 \\
Acting out & 31.2 & 30.2 & 61.4 \\
\hline TOTAL & 151.4 & 135.0 & 286.4
\end{tabular}




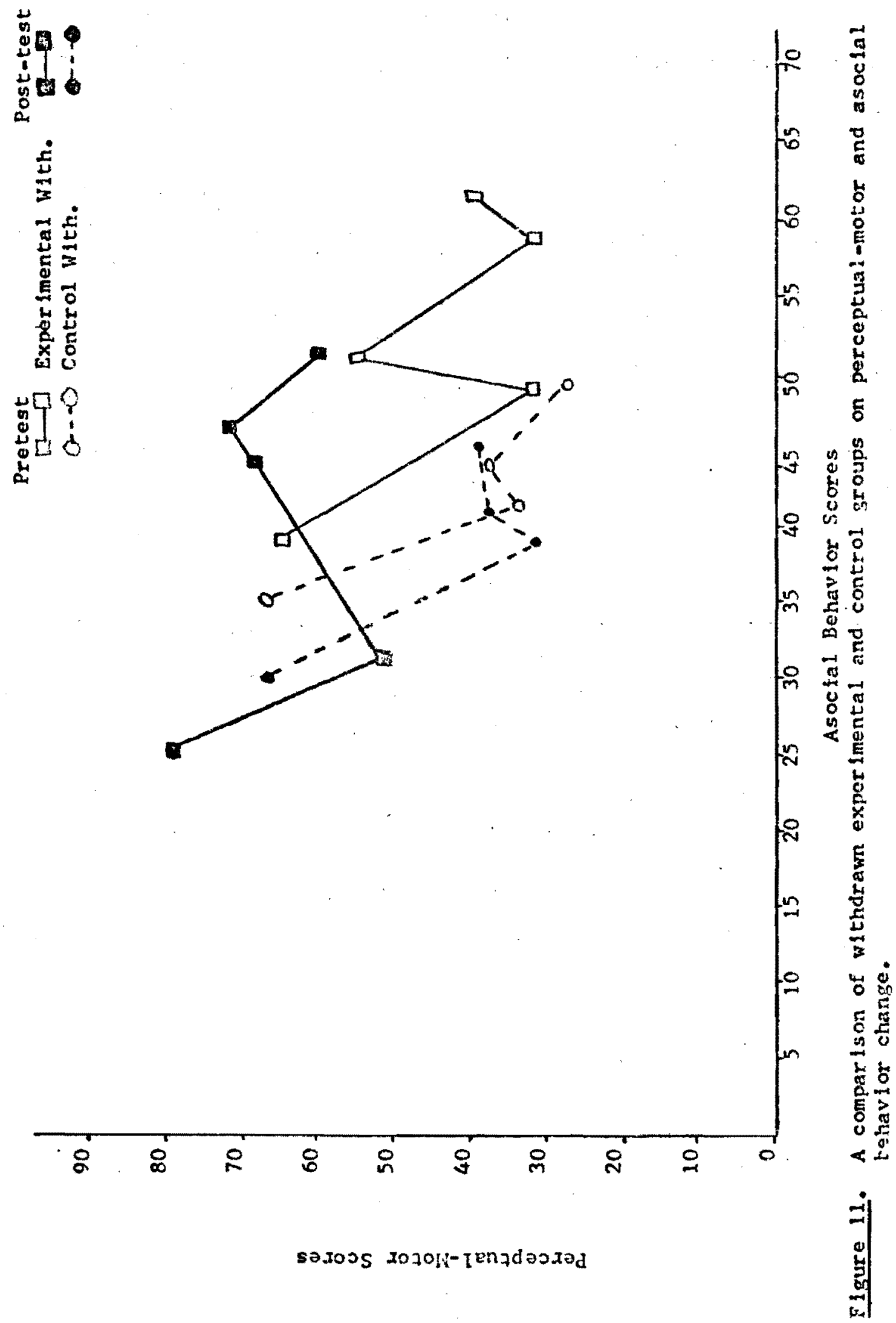


There was a slgniflcant difference between the withdrawn experimental and the withdrawn control subjects in asoclal behavtor change. Whereas, therc was littlo difference between the acting out experiemental and the acting out control subjects. The asoclal behavior appeared to change as an effect of the perceptual-motor training for withdrawn children. Thls relationship can be seen in Figure 11. The training had 1ittle effect on the asoclal behaviors of acting out children. This relationship is evident as seen In Figure 12.

Analys is of Behavioral Improvement Between Agencies

An analys is of variance was computed on behavior change between agencles. An analys is of thls type was felt to be necessary because the three agencles Involved in the study represented three different types of treatnent phllosophy. A summary of this analysis is presented in Table XI. A significant difference was found between

TABLE XI

SUMMARY OF ANALYSIS OF VAR IANCE OF BEHAV IOR CHANGE BETWEEN AGENCIES

SOURCE

Between Subjects

A (Treatment)

B (Agency)

$A B$

Between Subj. Error

Within Subjects

$C$ (pre and post tests)

$A C$

$B C$

$A B C$

Within Subj, Error

Total
SS

\begin{tabular}{|c|c|c|c|}
\hline $6,599.72$ & 59 & & \\
\hline $\begin{array}{r}207.24 \\
1,949.34 \\
382.89 \\
4,060.25\end{array}$ & $\begin{array}{r}1 \\
2 \\
2 \\
54\end{array}$ & $\begin{array}{r}207.240 \\
974.670 \\
191.445 \\
75.190\end{array}$ & $\begin{array}{c}2.756 \\
12.963 * * \\
2.546\end{array}$ \\
\hline 675.78 & 60 & & \\
\hline $\begin{array}{r}348.99 \\
164.07 \\
52.92 \\
21.30 \\
88.50\end{array}$ & $\begin{array}{r}1 \\
1 \\
2 \\
2 \\
54\end{array}$ & $\begin{array}{r}348.990 \\
164.070 \\
26.460 \\
10.650 \\
1.637\end{array}$ & $\begin{array}{c}213.207 * * \\
100.226 * \\
16.163 * \\
6.505 *\end{array}$ \\
\hline $7,275.50$ & 119 & & \\
\hline
\end{tabular}



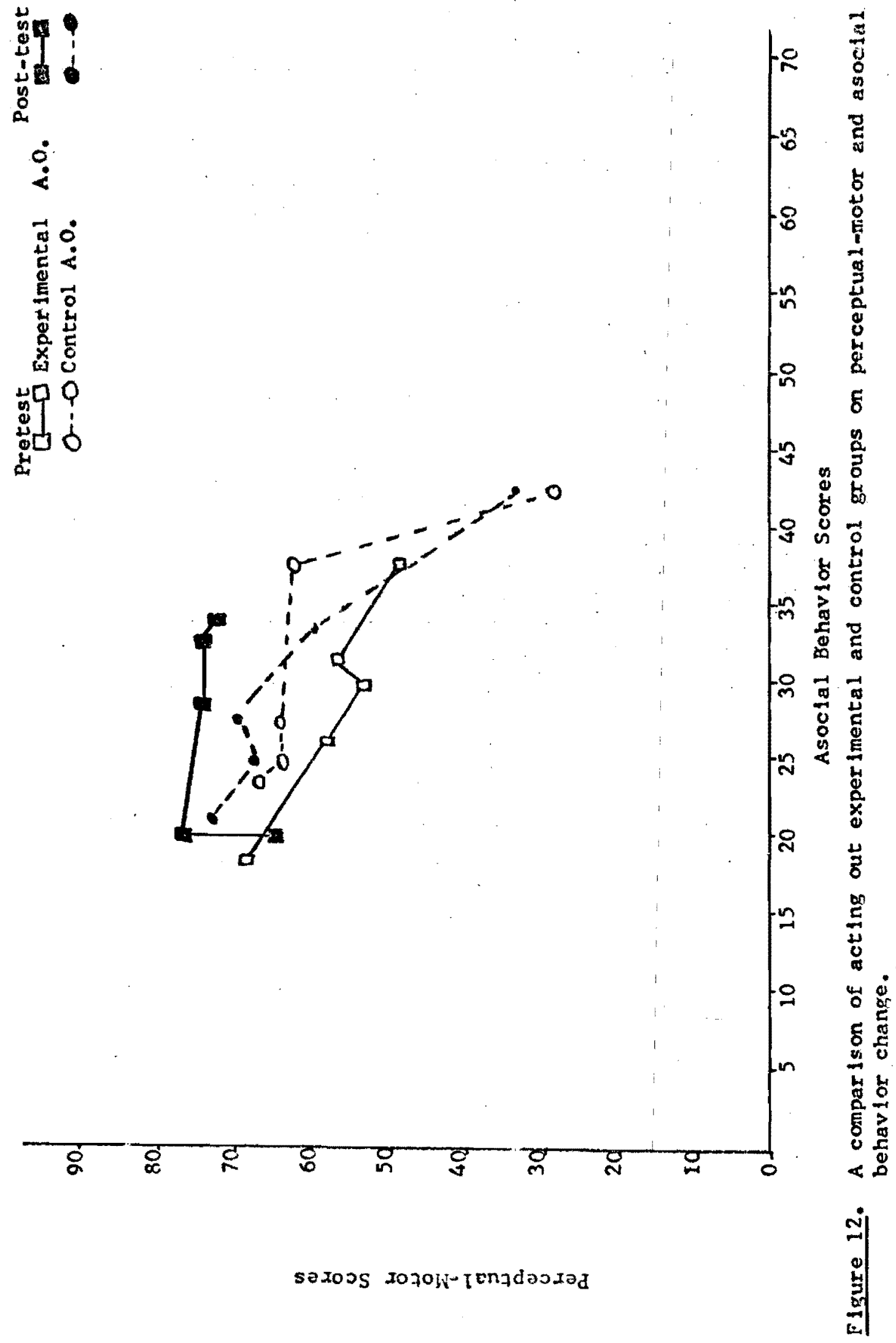
agencles on behavior scores. Ihls was significant at .01. There was a signiflcant change in behavior scores over time, signlficant at .01 . All of the subjects improved from the treatment recelved at the three different agencles. The treatrent of the experiment had a significant effect on the behavtor sccres and simllar to the effect shown in the analysis of varlance for the total behavlor scores, it was significant at .01. This relationship is presented in Figure 13.

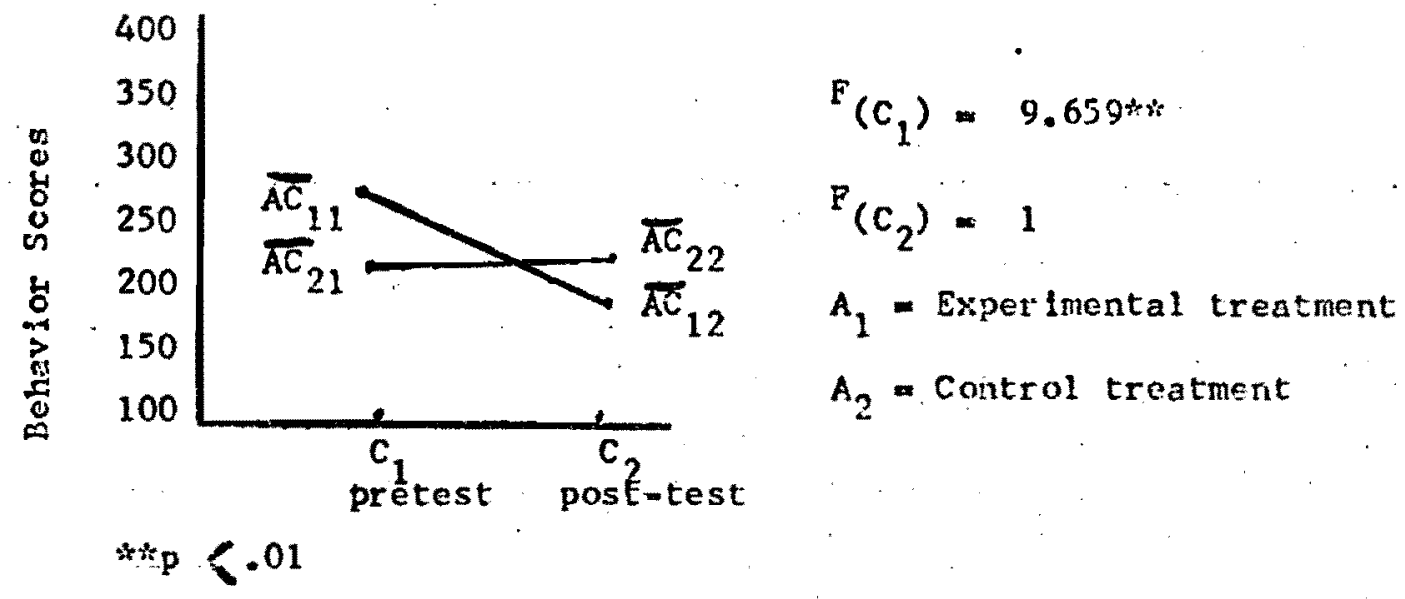

F1gure 13. Treatment and behavior change over time

The relationship between agency and behavior scores over time was found to be signiflcant at .01 . Thls relationship, which is demonstrated in Figure 14, indlcates that improvement in behavior varied

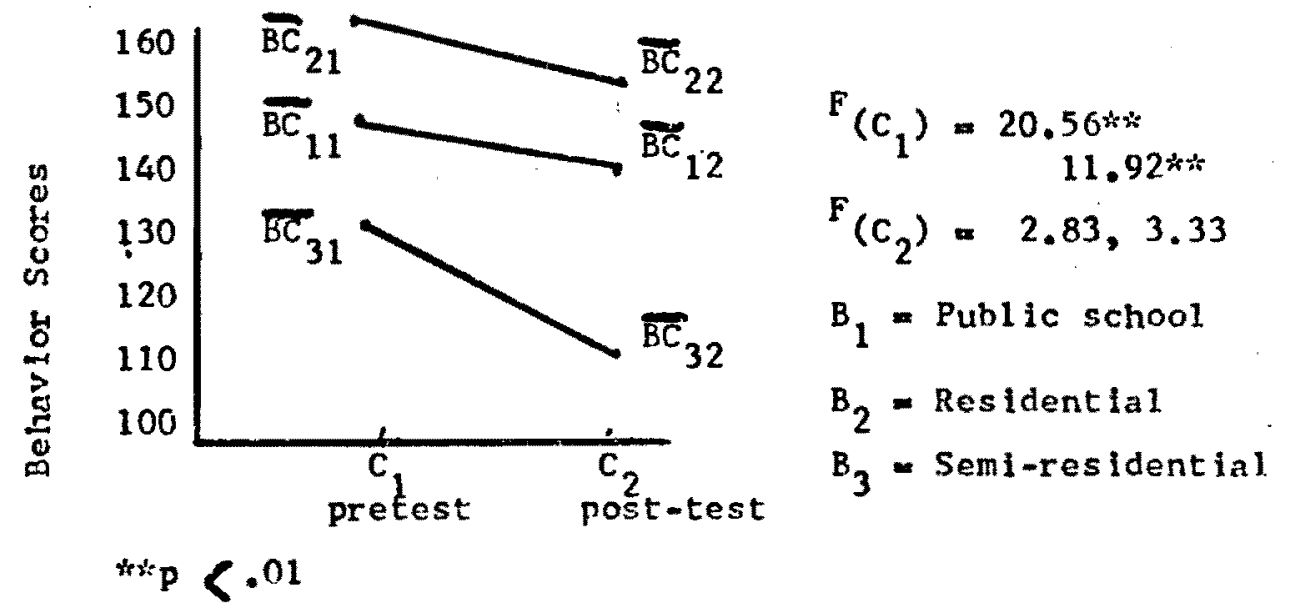

Figure 14. Azency and behavior change over time 
between the agencies. The behavior scores were effected over time by treatment and agency combinations. This relationship, illustrated in Figure 14, indicates that imapovenent in behavior varied between agencies and experinental conditions. The behavior scores were effected over time by treatment and agency combinations. This relationship, illustrated in Figure 15, was significant at .05 . Table XII also points out this relationship effectively. The subjects who were in

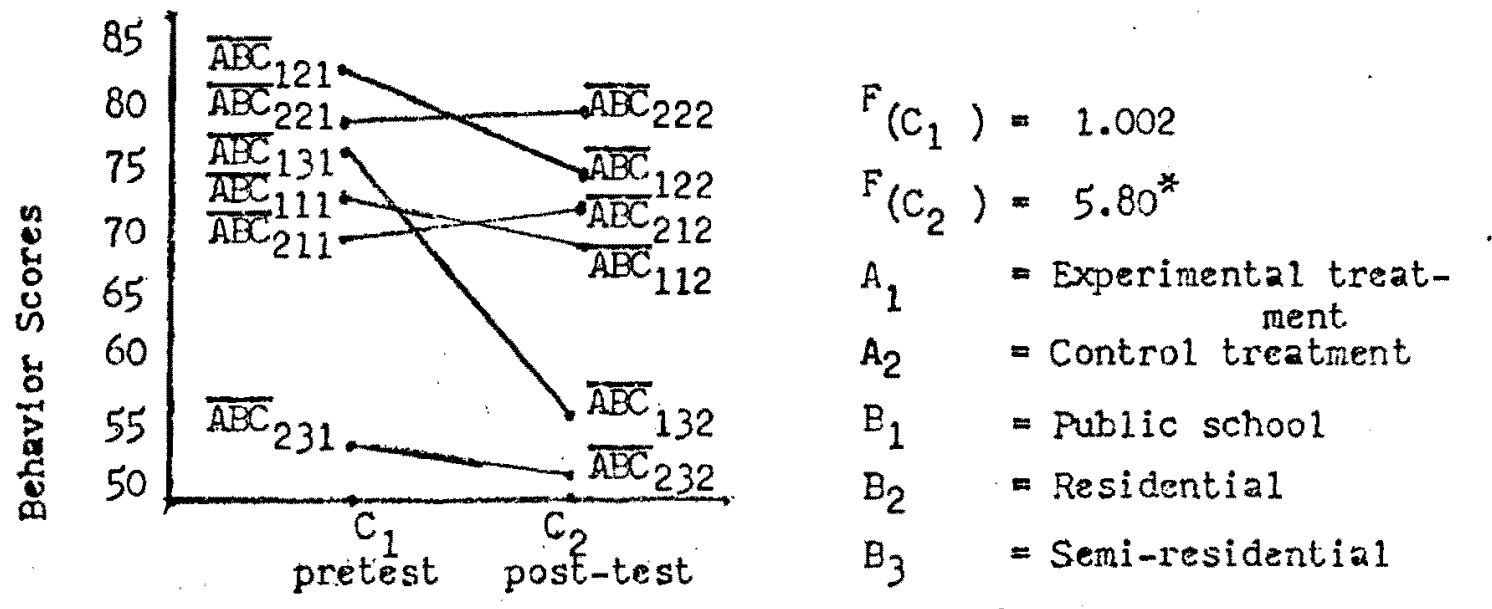

Figure 15. Treatment, agency and behavior change over time

TABLE XII

MEAN SCORES FOR THE BEHAVIOR SCORES OF AGENCIES

Pre

\begin{tabular}{llll} 
& Pre & Post & Total \\
\hline EXPERDEENTAL & & & \\
Public school & 73.00 & 68.50 & 141.50 \\
Residential & 80.50 & $70.25^{*}$ & $150.75 *$ \\
Semi-residential & $74.00^{*}$ & $57.00^{*}$ & $131.00^{*}$ \\
\hline CONTROL & & & \\
Public school & 70.00 & 69.00 & 139.00 \\
Residential & $77.25^{*}$ & 76.75 & 154.00 \\
Semi-residential & $53.00^{*}$ & $50.25^{*}$ & $103.25^{*}$ \\
\hline TOTAL & 427.75 & 391.75 & 819.50
\end{tabular}

* Figured from 2 scores. 
the experimental condition and the semi-residentlal treatment agency showed the greatest amount of inpovement. The next largest improvement came from experimental subjects in the residentlal treatrent agency, but the least amount of improvement was among control subjects In the residential treatment agency.

A graph, (Figura 16), was made comparing perceptual-motor ability and behavloral change between the agercies. The figure demonstrates the difference between the agencles on behavioral improvemènt. Differences in perceptual-motor abilities shows up only betwacn experimental and control subjects with some difference between withdrawn and acting out subjects, especlally prior to the treatment. 


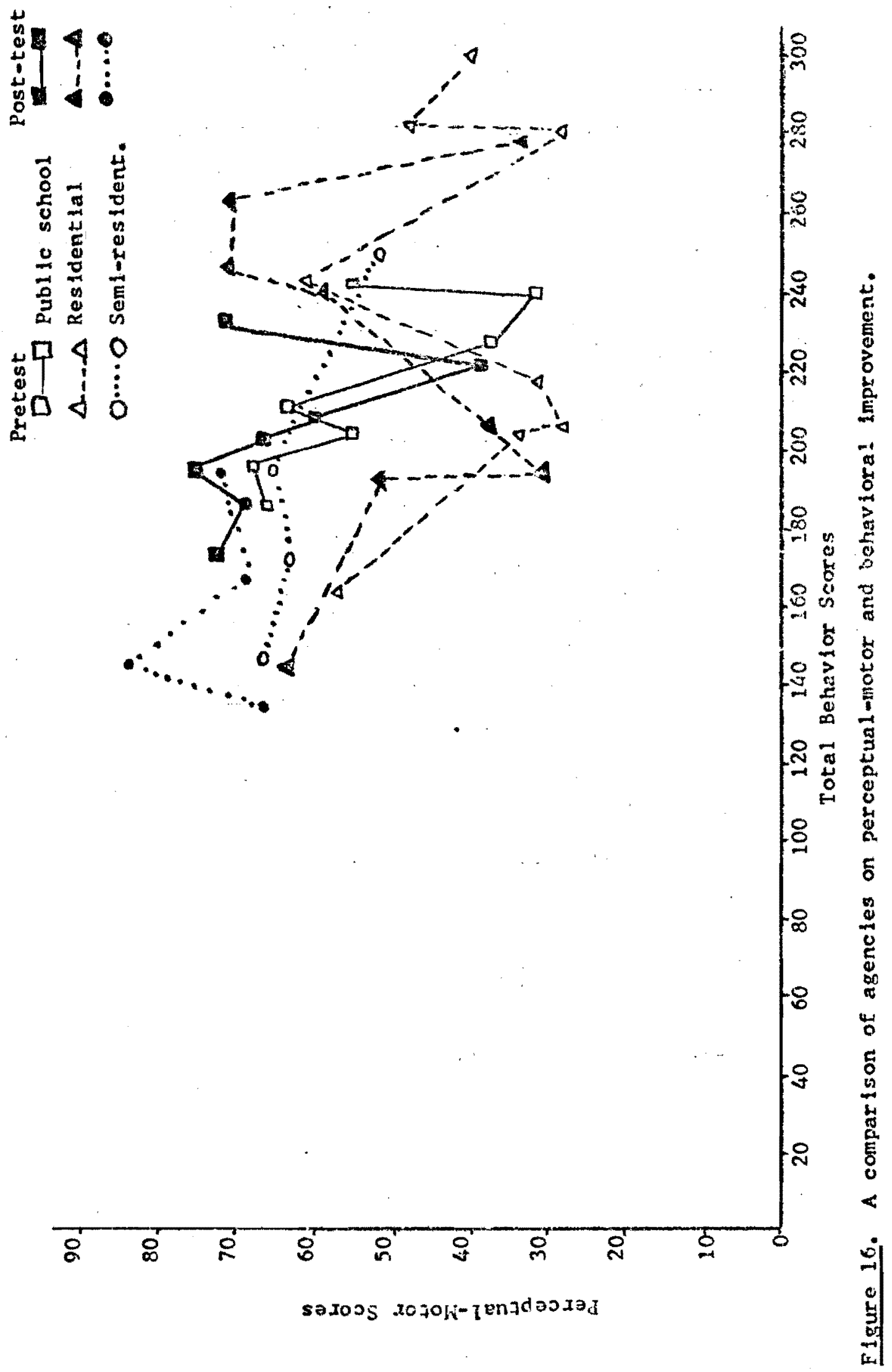




\section{CHAPTER IV}

\section{SUMARY, DISCUSSION, AND CONCLUSIONS}

\section{SUMMARY}

Twenty emotionally disturbed children between the ages of six and twelve from three agencies providing special treatment for behavioral or emotional problems were the subjects for this study. The subjects were divided into two major diagnostic categories, withdrawn and acting out, and then matched in pairs by age and diagnosis. One half of each pair was randomly assigned to the experimental condition and the remaining halves were assigned to the control condition. Both the experimental and control groups contained five withdrawn and five acting out subjects. Four experimenters were used, and each experimenter worked with two or four experimental children and their matched control subjects.

The Purdue Perceptual-Motor Survey was adninistered to all the subjects prior to the experiment and behavior ratings of maladaptive behaviors were obtained on each child from three adults who worked closely with the child. Using the methods outlined by Kephart and Radler in Success Through Play, (1960), the experimental subjects received perceptual-jotor training for one half hour three times a week for nine weeks. The control subjects recelved individual adult attention for the same amount of time in the form of activities and games.

At the and of the nine weeks the subjects were tested with the Purdue perceptual-riotor Sulvey and new behavi or ratings were obtained. The behavior scale was analyzad as a total score and then two subscores were obtained for anti-social and asocial behaviors. The anti-social and asocial subtests contained five tehavioral items each and were designed to give a nore sensitive measure of maladaptive behavior, especially for witharawn subjects. Prior treatment 
experiences with withdrawn children have established that these children often display an increase in aggressive or anti-social behaviors as their withdrawn or asocial behaviors decrease. Analysis revealed that: 1) The experimental subjects' perceptual-motor scores increased more than the control subjects' perceptual-motor scores, especially zmong withdrawn subjects; 2) The training had little effect on the maladaptive behaviors of the acting out subjects. The experimental acting out subjects improved behaviora11y, but not significantly more than the control acting out subjects; 3) The training had a significant effect on the maladaptive behaviors of the withdrawn children. The total behavior scores and the asocial behavior scores of the experimental withdrawn children improved significantly, and their antisocial behavior scores showed little change.

The subjects of the study came from three agencies with different treatraent philosophies. The experimenter felt it would be of interest to determine behavioral improvement differences between agencies. It was felt that this night suggest that a particular type of treatment would be more effective to use in conjunction with perceptual-inotor training.

One agency was a public school with special classrooms for emotionally disturbed children which exclusively used behavior modification techniques. Another agency was a residential treatment center which was designed for a milieu therapy, in which the children are totally removed from the home. The third agency was a semi-residential treatment center which used a combination of milieu therapy and behavior modification techniques. The children of this agency return home for weekends. There were equal numbers of acting out, withdrawn, experimental and control subjects within any single agency. An analysis of the amount of behavioral improvement within each agency revealed that there was significantly more improvement among the subjects from the semi-residental treatment agency. 


\section{DISCUSSION}

There were rany $1 \mathrm{im}$ tations to this study and further study is indicated. A stallar type of study needs to be perforned where the behavlor raters are trained. The raters for this study were not trained for observing behaviors and rating their frequency. Although there were specific instructions as to the frequency of a behavior on the rating scale, there were several discrepancles on a specif ic behavior of a particular child. In nearly every case, howevcr, this problem was compensated for by using the average of three raters. Usually the differences were small enough so that the average rating was a good representative of the frequency.

The training procedures and the perceptual-motor abilities test used in this study were both developed by Kephart. Several of the items used in the training were also a part of the test. If the study should be replicated another test, (one not designed by kephart), should 'ye used.

There was inadequate representation of emotional and behavioral problems of children in this study. Some types of emotional problems, such as school phobla, were not present in the study. Perhaps a random sample larger than twenty would include more of a variety of emotional and behavioral problems.

This study did not find deficiencles in perceptual-motor development among these childyen as other studies have found. The acting out children were found to be close to age level on all of the test items except ocular control. The withdrawn subjects vere, however, deficlent in many of the areas. All of the children appeared to have difficulty with ocular control. It was interesting to note that the tralning had little or no effect on their ocular difficulties.

Previous research indicated that perceptual-motor training had no effect on maladaptive behaviors of emotionally disturbed chlldren.

This stury found that the training had a slgniflcant effect on the maladaptive behavioss of children with certain types of enotional problems. Children who were withdrawn, chlldhood schizophrenic, and 
autistic displayid a signtflcant amount of behavioral improvement as a result of the tralning. It hould be of interest to test these children again in siz months to see if the effect was a. long range one.

As the training progressed the experimenters and raters indicated that they noticed an increase in the attention span of the withdrawn subjects who were in the experimental condition. They also noted a decrease in the amount of time spent halluclnating among the autistic and schizophrenic childzen. It appeared to the experimenters that perhaps these children were more able to identify the differences between themselves, others and ojjects in their environment.

The subjects from the semi-residential agency improved more hehavlorally than subjects from the other two agencles. This improvement may be accounted for by the use of more than one type of treatment, (milleu therapy and behavics modification), and by the agency's close work with each child's pazents. This agency required that the parents of the chlldren admitted for treatment cooperate with the social workers and receive counseling and directlon from them. The other two agencles did not require this of the parents, in fact, one agency had several children who were wards of the court.

\section{COHCLUSIONS}

Perceptual-motor training improves perceptual-notor abilities in emotionaly disturbed children. The withdrawn subjects scored lower in perceptial-motor abllities than the acting out subjects prior to the training. The withdrawn subjects who received the training improved more in perceptual-motor abilities as a group than any of the other groups. The resules of this study indicate that perceptual-motor training is an effective method of increasing perceptualmotor abilitles among disturbed childien, especially withdrawn chil: ren.

Mos: of the subjects involved in the study improved behaviorally during the course of the study. The acting out subjects who received the training improved a small amount more than those subjects whio did not recelve the training. The withurawn subjects who recelved the 
training, however, improved to a signifleant degree. These subjects, diagnosed as withiraw, childhoud schizophrenic and autistic, displayed a tremendous decrease in sialadaptive bchaylors from before training to after training behavior ratigs. For all withdravn sub= jects who received the training the 1 asocial scores decreased to a signiflcent degree. This effect was not present among the withorawn subjects who did not recelve the training.

The findings of this study suggest that perceptual-motor trainIng can be used effectively as partial treatment for withdrawn, childhood schizophrenic and autistic chlldren. Children with behavioral problems, which are aggressive or destructive in nature, might benefit as well from a resular physical education prograti in conjunction with treatrent for their behavior disorders. 


\section{REFERENCES}

Allen, Robert M. 1969. "An Empirical Tautology", Perceptual and Motor Skills, Vol. 29, No. 1, p. 50.

Argenti, Rudolph M. 1969. "The Effects of Systematic Motor Training on Selected Perceptua 1-Motor Attributes of Mentally Retarded Children", Dissertation Abstracts, 29 (11-A), 3853.

Ayres, A. Jean 1963. "The Davelopment of Perceptual-Motor Abilities: A Theoretical Easis for Treatment of Dysiunction", American Journal of Occupational Therapy, Vol. 17, No. 6.

Ayres, A. Jean 1965. "Patterns of Perceptual-iNotor Dysfunction in Children: A Factor Analytic Study", Perceptual and Motor Skills, Vo1. 20 , No. 2 .

Ayres, A. Jean 1969. "Relation Between Gesell Developmental quotients and Later Perceptua1-Notor Performance", Anerican Journal of Occupational Therapy, Vo1. 23, No. 1, pp. 11-17.

Barsch; Ray H. 1969. Enriching Perception and Cognition, Vo1. 2, Special Child Putications, Inc., Seatte, Washington.

Berkowitz, Pearl H. 1961. "Some Psychophysiological Aspects of Mental Illness in Children", Genetic Psychological Monograph, Vol. 63.

Cowe11, Charles C. and A. H. Ismail 1962. "Relationships Between Social and Physical Factors", Research Quarterly, American Association of Health and Physical Education and Recreation, Vo1. 33, pp. 40-43.

Cratty, Bryant 1964. Movement Behavior and Motor Lcarning, Lea \& Febiger, Philadelphiz, Penn.

Delacato, C.H. 1959. The Treatment and Prevention of Reading Problems: The Neuro-Psychological Approach, Chartes C: Thomas, Springfield, Tlinois.

Delacato, C.H. 1963. The Diagnosis and Treatnent of Speech and Reading Problems, Charles C. Thomas, Springfield, IIlinois.

Dempsey, Yvonne G. 1969. "An Exploratory Study of the Balance Performance of Educable Mentally Retarded Children in Southern Illinois", Dissertation Abstracts, 29 (11-A), 3856-3857. 
Doman, Robt., Eugene Spitz, Eliz. Sucman, Carl Delacato, and Glen Doman 1960. "Children With Severe Brain Injuries", Journal of American Medical Association, September, Vol. 174, pp. 257-262.

Ebersole, Marylou Newe11 C. Kephart, and James B. Etersole 1968. Steps to Achievenent for the Slow Learner, Merril1 Publishing Co., Ohio.

Edgar, Clara Lee 1967. "Perceptual-Motor Training as an Aid to Development of Reading Abilities," Clarement Peading Conference.

Edson, Thomas 1969. "Physical Education: A Substitute for Hyperactivity and Violence," Journal of Health, Physical Education and Recreation, September, Vol. 40, No. 7, p. 80.

Elfverson, Marilyn and Alfred W. Clark 1969. "Disruptive Effects of Contradictory Social Demands," Psychological Record.

Eleishman, Edwin A. and Simon Rich 1963. "Role of Kinesthetic and Spacial-Visual Abilities in Perceptual-Notor Learning," Journal of Experimental Psychology, Vol. 66, No. 1, pp. 6-11.

Fretz, Bruce R., Warren R. Johnson, and Julia A. Johnson 1969. "Intellectual and Perceptualmotor Development as a Function of Therapeutic Play," Research Quarterly, Vo1. 40, No. 4, pp. 687-691.

Goetzing, Cornelius P. 1961. "A Re-Evaluation of the Health Railwa1king Test," Journal of Educational Research, Vo1. 54.

Grass, Joseph R. 1968. "Performance and Reminiscence of Brain Damaged, Eehavior Disordered, and Nomal Children on Four Psychomotor and Perceptual Tasks," Journal of Abnormal Psychology, Vol. 73, No. 3, pp. 492-499.

Grossman, Herbert 1965. Teaching the Enotionally Disturbed, Holt, Rinehart and Winston, Inc., New York.

Hafner, Marjorie S. 1969. Motor Control and First Graders Reading Difficulties," Dissertation Abstracts, 29 (11-A), 3913.

Hurley, Oliver L. 1968. "Perceptual Integration and Reading Protlems," Journal of Exceptional Children, November, Vol. 35, No. 3, p. 208 .

Ilg, Frances L. and Louise Bates Ames 1965. Gesel1 Institute of Child Developinent, Harper and Row, New York, New York.

Jacobson, Virginia 1966. Movement Experiences and Learning: A Motor Development Progran for Young Chilaren," Claremont Reading Conference. 
Kahn, Aman U. 1968. "Effect of Training for Visual Motor Difficulties in Severely Disturbed Children," Perceptual-Motor Skills, Vol. 26, p. 744 .

Kephart, Newe 11 C. 1960. The Slow Learner in the Classroom, Charles E. Merrill Books, Inc., Columbus, Ohio.

Kephart, Newe11 C. 1963. The Erain In jured Child in the Classroon, National Society for Crippled Children and Adults, Inc.,

Kephart, Newell C. 1964. "Perceptual-hotor Aspects of Learning Disabilities," Journal of Exceptional Children, December, Vol. 31 , No. 4, P. 202 .

Kephart, Newe11 C. 1968. Learning Disability: An Educationa1 Adventure, Kappa De1ta Pi Press, West Lafayete, Indiana.

Kirkend211, Don R. 1969. "Relationship Among Motor, Ints1lectua1, and Personality Domains of Development in Preadolecent Children," Dissertation Abstracts, 29 (11-A), 3860.

Knoblock, Peter 1964. Educational Programming for Emotionally Disturbed Children: The Decade thead, Syracuse University Press, New York.

Lazroe, James J. 1969. "An Investigation of the Effects of Motor Training on the Reading Readiness of Kindergarten Children," Dissertation Abstracts, 29 (8-A), 2609-2610.

Lietz, Enno S. 1969. "An Investigation of the Perceptual-Motor Abilities of the Economically Disadvantaged Kindergarten Child as Compared to the Advantaged Kindergarten Child," Dissertation Abstracts, $29(10-A), 3530$.

Llorens, L. A., E. Z. Pubin, J. Braun, G. Beck, N. Mottley, and D. Beal1 1964. "Cognitive and Perceptual-Motor Functions: A Preliminary Report on Training In," American Journal of Occupational Therapy, Vo1. 18, No. 5, pp. 202-207.

McCormick, Clarence C. 1965. Hyperkinesis, Reading Disability and Perceptual-Motor Training: A Research Report and Discussion, pp. 1-15.

McCormick, Clarence C., Janice N. Schnobrich, S. Willard Footlik and Betty Poetser 1968. "Improvement in Reading Achievement Through Perceptual-Mot or Training," Research Quarterly, Vol. 39, No. 3, pp. 627-633.

Nurcombe, Barry 1967. "Learning Disability and Emotional Disorder," Slow Learning Child: The Australian Journal on the Education of Backward Children, Vo1. 14, No. 2, pp. 88-96. 
D'Conner, Colleen M. 1059. "The Effects of Physloal Activities Upon Notor Ability, Perceptual Ability and Academic Achievement of First Graders", Disscrtation Abstracts, $29(12-A), 4310$.

Palnter, Genevieve 1963. "Penedlation of Haladaptive Behavior and Psycholingulstic Deficits in a Group Sensory-Notor Activity Program", Acadomic Therapy Quarterly, Vol. 3, No. 4, p. 233.

Plaget, Jean 1952. The Crigins of Intell1gence in Children, Inter. national University Eress, New York, p. 123.

Radler, D. H. and Nerell r. Kephart 1960. Success Through Play, Harper and kow Publishers, Inc., New York.

Roach, Eugene and Newel1 C. Kephart 1966. Purdue Perceptual -Yotor Survey, Charles E., Merr 111 Books, Ine., Columbus, Onio.

Robbins, Melvyn P. 1966 "A Study of the Validity of Delacato's Theory of Neurological Organlation", Journal of Exceptional Children, Apri1, Vol. 32, pp. 517-523.

Safrin, Renate kersten 1964. "Differences In Visual Perception and in Visual-1otor Functioning Between Fsychotic and Non-psychatic Children", Journal of Consulting Psychology, Vol. 28, No. 1 .

Stravrlanos, Bertha K. and Sylvia C. Landsman 1969. "Personalify Patterns of Deficient Readers with Perceptual-Notor Problems", Psychology in the Schools, Vol. 6, No. 2 .

Van Witsen, Betty 1967. Eerceptual Tralning Handbook, Teachers' College Press, New York, New York.

Werner, Enmy E., Ken S Imonian and Ruth Smith 1967. "Reading Achicvement, Language Functioning, and Perceptual-Motnr Development in 10 and 11 year olds", Perceptual-Yotor Ski11s, vol. 25 (2), pp. 409. 420 .

Wigzins, S. L., J. R. Brokaw, R.V. Heckel and H, C. Salzberg 1962. "Manifest Anxiety and Perceptua1-Motor Steadiness," Perceptual and Motor Skilis. Vol, 15, No. 3. 


\section{APFENDICES}

APPENOIX

PASE

A Purdue Perceptual-Yotor Survey ................... 46

B Administration Procedures For the Purdue Perceptun -

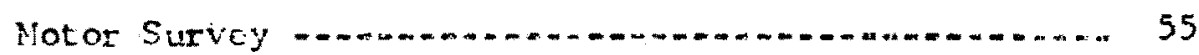

c. Scoring frocedures for the Purdue Perceptual-ioto:

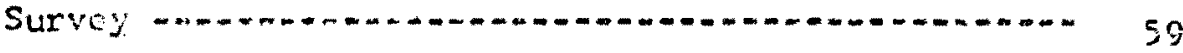

D Equipment used in the Purciue Perceptund motor Survoy

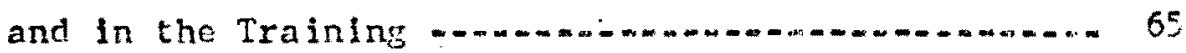

E Hall's Behavioi Rating Scale ........................ 67

F Ha11's Anti-Social Behavior Subscale ................... 69

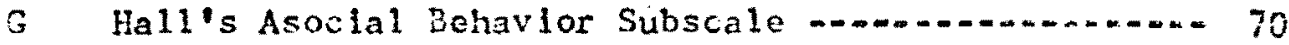

H Progress Chart Used for the Experimental Group ..... 71

I Activity Record Used for the Experimental Group .... 73

.J Activity Record Used for the Control Group .......... 7t.

\& Date Sunmary Sheets

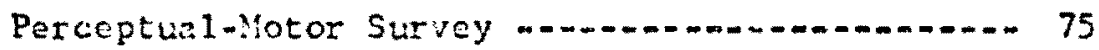

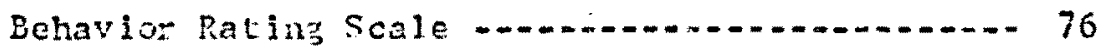

I Raw Da:a

Raw Soores n...

Bar Graphs Using Raw Scoics ................... 79

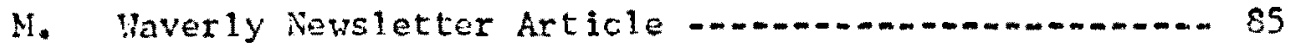


Name Date of Birth

Agency Sex Grade

Diagnosis

Examiner Date of Examination

\begin{tabular}{|c|c|c|c|c|c|}
\hline & & Scor & & & \\
\hline & 4 & 3 & $?$ & 1 & \\
\hline $\begin{array}{l}\text { Walking Board } \\
\text { Forward } \\
\text { Backward } \\
\text { Sidewlse }\end{array}$ & & & & & 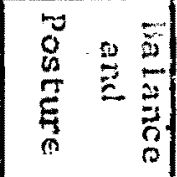 \\
\hline $\begin{array}{l}\text { Jumping } \\
\text { Identificat on of Body Parts } \\
\text { Initation of Movement } \\
\text { Obstacle Course } \\
\text { Kraus-heber } \\
\text { Angels-in-the-Snow }\end{array}$ & & & & & 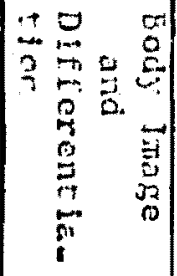 \\
\hline $\begin{array}{l}\text { Chalkboard } \\
\text { Circle } \\
\text { Double Circle } \\
\text { Lateral Line } \\
\text { Vertlcal Line } \\
\text { Rhythmic Writing } \\
\text { Rhythm } \\
\text { Reproduction } \\
\text { Orientation }\end{array}$ & & . & & & 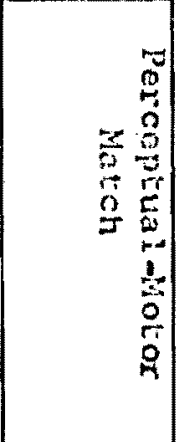 \\
\hline $\begin{array}{l}\text { Ocular Pursuits } \\
\text { Both Eyes } \\
\text { Right Eye } \\
\text { LeEt Eye } \\
\text { Dush-Vp }\end{array}$ & & & & & $\begin{array}{ll}7 & 0 \\
9 & 0 \\
2 & 2 \\
7 & 0 \\
0 & 9 \\
0 & 7\end{array}$ \\
\hline $\begin{array}{l}\text { Visual Achieverent Forms } \\
\text { Form } \\
\text { Orzanlzation }\end{array}$ & & & & & 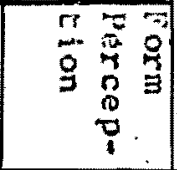 \\
\hline
\end{tabular}

Furdue Universily

Lafayette, Indiana 
BALANCE AND POSTURAL FLEXIS IL ITY

1. WAIZING BOARD

Steps off buard

Fozvard

Pauses frequently

Uses one side of body more consistently than other

Avoids Balance:

Runs

Long steps

Feet crosswise of board

Malntains inflexible posture

Score

Bachward

Steps off board

Comments:

Pauses frequentiy

Uses one side of body more consistently than ather

Avolds Balance:

Runs

Long steps

Feet crosswise of board

Twists body to see where he is going

Must look at feet

Maintains inflexible posture

Score

Sidewise

Unable to shlft welght from one

Comments:

foot to the other

Confusing or hesitation in

shiting welght 
Crosses one foot over the other

Steps off board

Performs more eas $11 y$ in one

direction than the other:

Right lead

Left lead

Score

2. JUMPING

\section{Both Feet}

Cannot keep both feet together

Uses one side of body only

"Ties" one side of body to the

other

One Frot

Postural shift not smooth

Comments:

Cannot keep opposite foot off

the floor

Performance better on one

foot than other:

Right

Left

Skip

Movement not free

Comments:

Hesitates after each step to determine which side to use

Hop

Cannot rema in in one spot while performing

Comments:

Cannot shift easily from side

to side

Movements jerky and lack rhythm:

All patterns

Asymetrical patterns only 
BODY IYAGE: AND DIFFERENT IAT ION

3. IDENTIF ICATION OF BODY PARTS

Show hesitancy in one or more

Comments: responses

Does not touch both nembers

of paired parts

Must "feel around" to flnd

parts

Makes more than one error in

identification

Sroire

4. IMITATION OF MOVEMENT
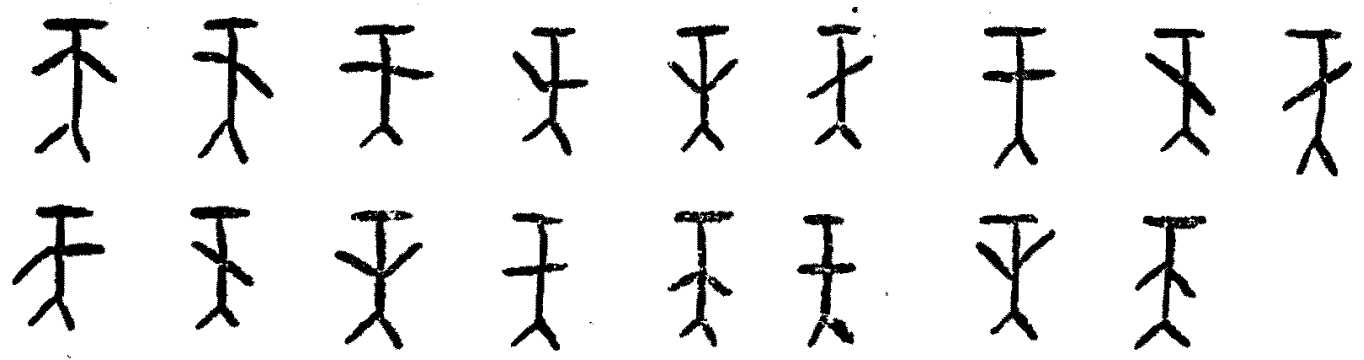

Does not mirror the patterns

\section{Comments:}

Not consistent (sometimes mirror, sometimes parallel)

Shows hesitation or lack of certainty

Makes abortive movements

Moves wroing $1 \mathrm{imb}$

Recognizes errors after some delay

Does not recognize errors spontaneously

5. OBSTACLE COURSE

\section{Going Over}

Gver-estimates (steps too high)

Comments: 
Catches foot on bax

Cannot correct on one repeti-

tion

\section{Going over}

Knocks bar off

Coinnents:

Bends too low to clear bar

Cannot correct on one repeti-

tion.

Going Between

Does not turn body

Comments:

Score

6. KRAUS-WEBER

Cannot raise chest and hold

Comments:

Cannot ralse legs and hold

Score

7. ANGELS-IN-THE-SNOW

Must $100 \mathrm{k}$ from one $1 \mathrm{lmb}$ to the other to identify

Conments:

Cannot identify by visual data al one

Requires tactual information to Identify $11 \mathrm{mbs}$

Taps or moves $11 \mathrm{mb}$ on floor to identify

Abortive movements to get started

Hesitation at beginning of movement

Movements are hesitant and jerky

Overflow into other 1 imbs than those called for

Movements do not reach maximum extension 
Requests repetition of instrue-

tions

Cannot correct response on one repetition

Score

PERCEPTUAL-NOTOR MATCH

8. CHAIKBOARD

\section{circle}

Does not reach proper size

Conments:

Direction incorrect for hand used

Drawing not directly in front of child

Does not cross midline

Shape of clrcle not accurate

Must stor to "think out" next

move during performance

Wrist is stiff and difficult

to control

Still shows difficulty after

3 or 4 attempts

Double Circle

Does not reach proper size

Comments:

First attempts are small and

far apart

Circles overlap

One clrcle larger than the other

One more accurate than the other

Circles diawn one on top of the

other

Direction incorrect

Hands parallel

Opposite but wrong direction 
Circles flat toward inside

Inaccuracles which are not parallel

in both circles

Visual attention directed to one hand

Movement of two arms not synchronized

Score

\section{Lateral Lines}

"Walks" across the board

Comments :

Draws left half with left hand,

right half with right hand

Pivots body to avold crossing

midl ine

Difflculty when hand is on

opposite slde of midline

False starts

Pauses and confusion

Inaccuractes

Score

Vertical Lines

Lines bow Markedly

S1ightly

Visual attention to one hand only

One hand ceases to function

during performance

Hands move alternately, not simultaneously

Score

9. RHYTHMIC WR ITING

Motifs

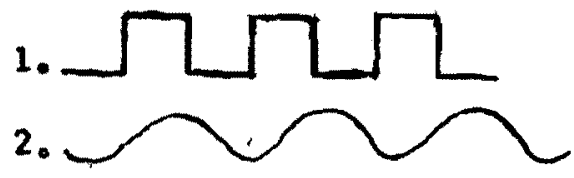

3. ereecer

4. lmalnentem 

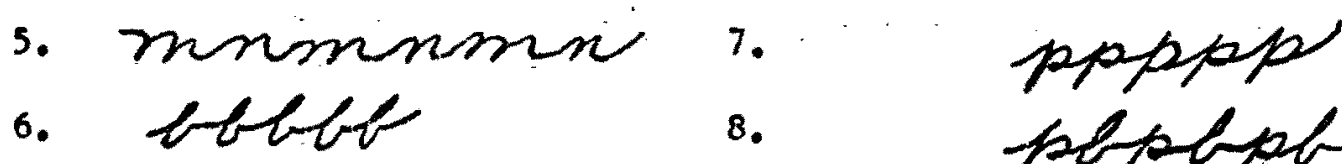

6.

8.

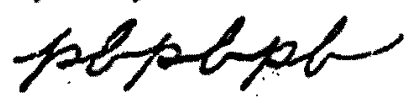

Hesitant and jerky

Movement cramped and Inflexible

Rhythri not constant

Directional reversals or confusion

Order reversals or confusion

I Ine of motifs slants

Characters in motifs slant

Inaccurate reproduction

Scores:

Size does not remain constant

throughout performance

Characters become smaller as

performance is sustained

Rhythm

Reproduction

Or ientation

Excessive movement of hips

or trunk

\section{OCULAR CONTROL}

10. OCULAR PURSUITS

Moves head instead of eyes

Comments:

Eye movements are jerky

Throughout

At extremes only

Movement jerk at midline

Eyes do not work together

One eye remains stationary as

other moves

One eye leads the other

markedly

Overshoots or undershoots

durling pursuit 
Looses $v$ Isual contact with

target during movement

Scores:

Then contact is lost, cannot

regain easily

Both eyes

One eye "wanders off" the

target

Throughout

At extremes only

Right eye

Left eye

Changes eyes at midline

Convergence

Convergence

Impossible at 4 inches

Sluggish

Uneven

FORM PERCEPTION

11. VISUAL ACHIEVEHENT FORMS

\section{Form}

Changes or ientation of paper

Conments:

to alter direction of movement

Segments drawings

Internal 1 ines of divided

rectangle segmented

"Ears" on forms

Drawing markedly larger or smaller than copy

Score

Organization

No discernfble organization

Comments:

Organlzation on page is:

Left to right

Vertical

Circular 


\section{APPENDTX B}

ALIINISTRATIOH PROCEDURES FOR

THE PURDUE PERCEPTUAL-MOTOR SURVEY

Test I - Halking Boàrd

The examiner says to the child, "Get up on the board and walk to the other end." When the child has reached the far end of the board, the examiner says, "Now walk it backward." When he has crossed the board again, the examiner says, Now walk it sideways." When he has walked the board sideways in one direction, the examiner says, "Now cone back sideways."

Test II -.. Jumping

The examiner says, "Place both feet together and jump one step forward." Next he instructs the child to "Siand on your right foot with your left foot off the floor and junp one step forward without putting your left foot down." Then he says, "Now stand on your left foot with your right foot off the floor and jump forward without putting your right foot down." The examiner then asks the child to skip across the room. The examiner next says to the child, "I want you to hop once on the right foot, then once on the left, once on the right, then laft, and so on." If the child stops, the examiner says, "kzep going." If the chila pauses between each hop, he says, "Can you go faster?" If he moves forward, the examiner says, "Stay in one place and keep hopping." Next the examiner says, "Now hop twice on your right foot, twice on your left foot, and keep going." Next the examiner says, mow hop twice with your left foot and once with your right and keep going."

Test III -- Identification of Body Parts

The exaniner says, Mouch your shoulders. Touch your hips: 
Touch your head. Touch your aniles. Touch your ears. Touch your feet. Touch your eyes. Touch your elbons. Touch your mouth."

Test IN-- Initation of yovemer:ts

The examiner says to the child, "I am golng to move ny arms and I want you to move your arms just 1 ike I do. Are you ready?" The examiner denonstrates the following positions:

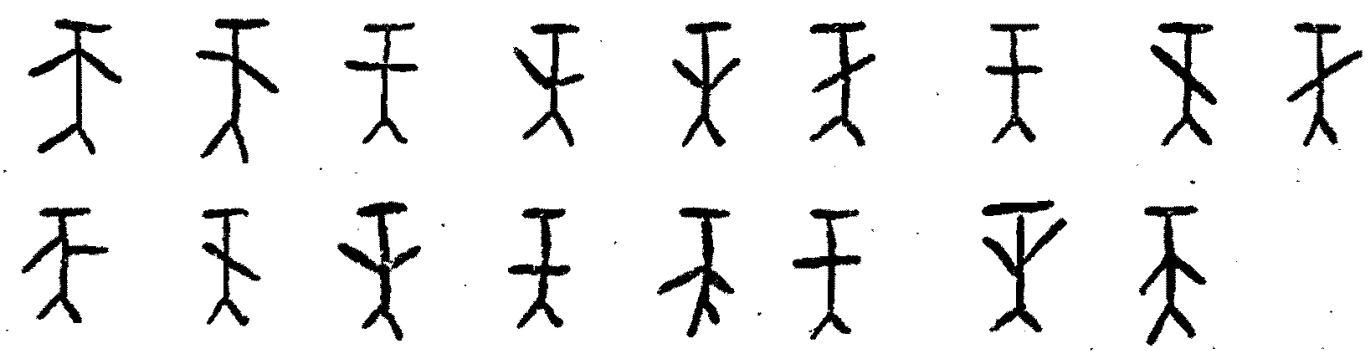

Test $V=$ Obstacie Coursa

The examiner tates a broom handle, placing it leve! with the child's knee height, says to the child, "step over the stick." placing the brom hardle about two inches below the child's shoulder height, the examinet says, "Duck unter the stick." Then the examiner puts the end of the brocm handle just far enough away from the wall so the child can get between the end of it and the vall if he turns his body sldeways. The examiner then says, "So betweon the wall and the stick without touching either."

Test YI - vaus Meyex

The examiner hes the child 1 le face dom on a rug or mat and tells him to place his hands behind his head and clasp his hants together. The examiner holds the child's feet and says, "Raise your head, shoulders, and chest off the floor while I count to ten." Then the examiner says to the child, "Put your hands beneath you face. Raise your lezs oif the floor whinout bending your knees whlle I count to ten." The exominer holds the child's chost down by placing a hand between his shoulder bladas. 
Test VII -. Angels in the Snow

The examiner asks the child to lle on hls back on a rug or mat with his lezs tozether and his arms at his sides. He says to the chlld, "move just this arm," pointing to the right arm. "Now move your arm back to your side." Then he says, "Move Just this arm", pointing to the left arm. "Now move 1 t back to your side. "Move just this leg", polnting to the right leg. "Now back together. Nove just this leg", pointing to the left leg. "Now back together. Move both arms. Now back. Move both legs. Now back. Nove this arm and this leg", the examiner now points to the left arm and left leg. "Now back. Move this ard and this leg", as the examiner points to the right arm and right leg. "Now back. Move this arm and this leg", the examiner Is pointing to the $r$ ight arm and left leg. "Now back. Move this arm and this leg", as he points to the left arm and right leg. "Now back".

\section{Test VIII - - Chalkbozrd}

The examlner glves the chlld a plece of chalk and says, "Dra: a circle." Next the examiner says, "Take a plece of chalk in each hand and draw two circles at the same time." Then the examiner asks the chlld to turn away so. he will not see the examiner place two "x's" about 24 to 30 inces apart on the chalkboard. The examiner says to the child, "Draw a line from one "x" to the other." Then the examiner places two " $x$ " $s$ " on the chalkboard in such a nanner that the chlld must extend his hand in order to reach them. The examiner says, "Take a plece of chalk in each hand and draw two straloht lines from the "x"s" to the botton of the chalkboard at the same time."

\section{Test IX - Rhythnic Writing}

The examiner places the first of elyt motifs just above the child's eye level on the chalkboard and says, "Copy this deslgn." The same procedure is followed for each of the other motifs. 
Test X - Ocula: Pursults

The examiner holds a penoil with the ezaser pointing towards the chlld's face, about eighteen to twenty-four inches away. He says, "Now watch the eraser wherever it goes." The examiner mored the pencil along the arc of a clrcle with a radius of about elghtuen or twenty inches, having its center at a point between the child's eyes. He moves the pencll approximately elghteen inches to the right and then back. Then approximately elghteen inches to the left and back. He then moves it up and down for approximately eighteen Inches, and then In each of the two diagonals (upper left, lower $r$ ight and upper $r i g h t$, lower left). The examiner then covers the child's right eye with a piece of cardboard and repeats the procedure. The examiner then covers the chlld's left eye with the cardboard and repeats the pro. cedure. The examiner then removes the cover and says, "Look at me." Then holding the pencil directly in front of the child and at the eye level of the child says, "Now look at the exaser." The examlner moves the eraser toward the child's nose.

Test XI -. Visual Achievement Forms

The examiner gives the chlld a pencil and plece of blank paper. The examiner presents design number 1 and says, "Copy this." The examiner repeats the procedure for all seven designs. 


\author{
APFEND IX C \\ SCORING PROCEDURTS FOR \\ THE DURDUE PERCEPTUAL-NOTOR SURVEY
}

Each of the test items in the Purdue Eerceptual-Notor Survey were scored according to Kephart's system of evaluation.

\title{
Walking Board
}

Forward: If the chlld walks easlly and maintalns dynamic body balance throughout, he recelves a score of 4 . If the child has occastonal difficulty but is able to regain balance each $t$ ime, he recelves a score of 3 . If the child steps off the board more than once or if he pauses frequently, he recelves a score of 2 . If the child cannot perform or If moze than one-fouth of his performance is out of balance, he receives a score of 1 . Sackward? If the child walks easily and maintalns balance throughout without looking behind him, he receives a score of 4 . If the chlld has occasional difficulty but is able to regain balance each time, he recelves a score of 3. If the chlld steps of the board nore than twlce, if he pauses frequently, or if he cannot perform without looking bohind hin, he recelves a score of 2 . If the child cannot perform, if he must feel with his toe, or If more than one half of his performance is out of balance, he recelves a score of 1 . Sideways: If the child walks easily in elther direction, he recelves a score of 4 . if the chlld has occasional difflculty but is able to regaln balance each $t$ ime, he receives a score of 3 . If the child steps of the board more than two intes in one direction or if he pauses frequently and has difficulty regaining balance, he receives a score of 2 . If the child cannot perform, If his performance is markedly better in onc alrection than the other, of if hls performence is markedly out of balance, he recelves a score of 1 . 
Jumping

If the chlld performs all tasks easlly, he recelves a score of 4. If the chlld can alternate sldes symotrlcally (all tasks), he recelves a score of 3 . If the child can hop on elther foot at will (the first five tasks), he recelves a score of 2 . If the child can only perform symmetrically (fever than five tasks performed adequately), he recelves a score of 1 .

\section{Identification of Body Parts}

If the chlld perfornis adequately throughout, he receives. a score of 4. If he shows only slight hesitancy or confustor, he recelves a score of . If the child shows hesitancy in more than one or two of the commands or if he points to only one of the paired parts, he recelves a score of 2. If the child is umable to identify one or more of the parts called for, If he shows marked hesitancy (oxcept elbows), or If he 'feels around' to find the part, he receives a score of 1 .

\section{Imltation of Novements}

If the child performs promptly, consistently, and surely on all. patterns and only if he parallels the pattern so that his movements are an exact duplicate of the examiner's, he recelves a score of 4 . If the child performs promptiy, consistently, and surely, but mirrors the examiner's movements, he recelves a score of 3 . If the child shows hesitation or a lack of certainty, he recelves a score of 2 . If the child makes more than one error or if there is abortive movement in several patterns, the child recelves a score of 1.

\section{Obstacle Course}

The cilid's performance is evaluate: on the basis of his performance on all three tasks.

4. If his performance is adequate throughout.

3. If he makes only a slight error wilch he corrects easily.

2. If he is able to correct hinselif on one repetition. 
1. If he over-estimates or under-estimates noticeably (more than two or two and one-half inches) and cannot correct this on one repetition.

Kraus-Weber

If the chlld passes both tests, he recelves a score of 4 . If the chlld falls the second test, he receives a score of 3 . If he falls the first, test, he recelves a score of 2 . If the chlld falls both tests, he recelves a score of 1 .

\section{Angels in the Snow}

If the child performs adequately throughout all the tasks, he recelves a score of 4 . If the chlld shows only slight hestancy in some of the patterns or if he shows restricted movenent or overflow which is corrected in one repetition, he receives a score of 3 . If the chl1d shows marked hesitancy in beginning the movements or if the extent of the movement becomes restrlcted in any of the patterns and he cannot correct this with one repetition of the instructions for that pattern, he recesves a score of 2. If the chlld cannot perform one or more of the tasks, if there is overflow to 1 imbe not required in the pattern and he cannot correct this overflow in one repetition of the instructions, if he requires tactual information in addition to visual information in any of the tasks, or if he must 'bang' the limb on the floor to identify it, he receives a score of 1 .

\section{Chalkboard}

Circle: If the circle is dram in proper size, direction, position and shape (one added instruction is allowed to achleve size and position), the child recelves a score of 4. If the child, after two or three trials, achieves a clrcle nearly correct in slze, position, and shape with only minor errors in shape, he recelves a score of 3. If the child contirues to show marked difficulty in performance although, with effort, he is able te produce an acceptable draving or if the direction of the drawing is incorrect for the child's pre- 
ferred hand, he recelves a score of 2. If the child is unable to produce a circle of proper size, location, or shape, if he is unable to cross the midline and continues to avold the problem, if he shows marked confusion in direction during the drawing, or if the drawing continues to be.distorted, especlally flatiness on one side or on the bottom, he receives a score of 1. Double circles: If the performance is smooth and certain with no more than one additional direction to achleve size and position, the child receives a score of 4 . If two or three trials are necessary to achieve the destred production or if the performance continues to be halting and stiff. The child receives a score of 3. In extreme difficulty is experlenced in any part of the performance, if the direction of the drawing is incorrect, or if the performance does not become acceptable within two or three trials, the child recelves a score of 2. If the child is unable to perform the task, if he cannot achieve drawings of acceptable size, shape and position, if he attends only to one hand, or if he draws circles which are distorted (flat) toward the center, he receives a score of 1 . Lateral lines: If the performance is adequate; the child receives a score of 4. If there is silght hesitancy and slight inaccuracy, the chlld recelves a score of 3 . If there is marked hesitancy or marked inaccuracy, the chlld recelves a score of 2 . If the child cannot perform the task or if his intlal attempts are by walking across or using two hands, the child receives a score of 1 . Vertical lines: If the performance is adequate and both lines are stralght and parallel, the child receives a score of 4 . If the child performs adequately but only after hesitation and consideration of the movements involved, he recelves a score of 3. If the Ilnes 'bow' slightly, but attention is directed to both hands, the child recelves a score of 2 . If the lines 'bow' markedly, all attention is directed to the preferred hand, or if the child cannot pe:forin; he recelves a score of 1.

\section{Rhythmic Witing}

Rhythm: If the performance is smooth, certain, and consistent with no more than one additional trlal to achieve size and position. the child recelves a score of 4. If three or four trials are 
necessary to achieve the desired rhythic performance, the child recejves a score of 3. If extreme difficulty is experienced in any part of the performance, the child receives a score of 2 . If the child is unable to perform the task, he receives a score of 1. Ren productions: If the performance approximates the same size and letter constancy of the motif presented, the child receives a score of 4 . If the performance shows decided tendency to make motifs larger or smaller than the sample motif, the child receives a score of 3 . If the performance reveals reversals and orisstons of components in the notifs, the child receives a score of 2. If the child is unable to perform the task, he receives a score of 1 . Orlentation: If the parformance is adequate in terms of direction and position, and follows a straight Iine course from one side of the body to the other, the chlld receives a score of 4. If the perfornance is slightiy slanted as the motifs are executed (either up or down), the child receives a score of 3 . If the performance demonstrates that the chlld is incapable of reproducing the motifs on an approximately horlzontal line, he recelves a score of 2. If the child is incapable of performing the task, he receives a score of 1 .

\section{Ocular Pursuits}

Tasks 1, 2, and 3: If the eyes move smoothly, evenly, and follow the movements, the child receives a score of 4 . If the eyes move basically smoothly, with only slight jerkiness or hesitation, the child recelves a score of 3 . If the movements are uneven os jerky, the child receives a score of 2 . If the chlld is basically unable to follow the target, loses the target, cannot follow the target without moving his head, or if parallelism between the two eyes is no established, the child recelves a score of 1 . Task 4: If there is smooth, even movement, the chlld recelves a score of 4. If the movement is basically smooth, with only slight delay or inaccuracy, the chlld recelves a score of 3 . If the movement is jerky and unsure or is grasp and release are slow or inaccurate, the child recelves a score of 2 . If the eyes break apart or do not converge, the chlld receives a score of 1 . 
Visual Achievement Forms

Form: If the performance is adequate throughout, the child recelves a score of 4. If there are minor distortlons, partlcularly In the diamonds, the child receives a score of 3 . If there is any segmenting in ary of the drawings, the child recelves a score of 2 . If there are 'dog ears' on the diamonds, gross segnenting, or if the child cannot produce a recognizable form in one or more of the draw ings, he recelves a score of 1. Organlzation: If the drawings are organized from left to $x$ ight or top to botton and. the size is adequate, the child recelves a score of 4. If other organization is complete or if more than four of the forms are organized on the page, the child receives a score of 3. If the size is markedly too smali or too large or if less than five of the drawings are organized on the page, the child recelves a score of 2. If no organization is apparent in the drawings, the child receives a score of 1 . 
APPENDIX D

EQUIPUENT FOR THE PUKDUE PERCEFTUAL-NOTOR SURVEY

All equiment used in both the testing and training frogram is built according to Kephart's specifications.

\section{Angels in the Snov}

A small throw zug is used for the child to lie upon while performing the preser lbed tasts.

Halking Board

An elght foot long section of $2 \times 4$ is placed between two braclets whlch are dlayranmed below. Testing is done on the four Inch side of the $2 \times 4$.

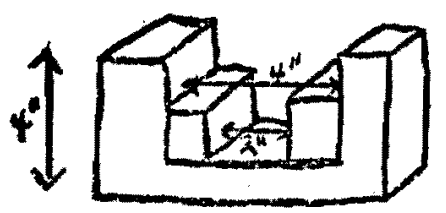

\section{Balance Eoardis}

A square platform, $16 \times 16$ inches is used for each balance board. Underneath the platform and centrally located is a small post, three inches high, attached to the board by a screw. Three sizes uE balance posts are used: $5 \times 5,4 \times 4,3 \times 3$ inches.

\section{Drawing Games}

A chalkboard, three feet by four feet or larger, is used. It should be without design. Also needed are several pleces of chalk and an eraser. 
Pegboard Games

Two pleces of pegbeard not smaller than $16 \times 20$ Inches and having at least 100 holes are used. Also used in place of pegs are the recommended 100 golf tees in equal amounts of each of five colors.

\section{Marsden Ba11}

A soft rubber ball atiout the size of a tennis ball is suspended by flshing line from the celling via an eyelet screw or similar means. The fishing ine is attached by threading it through the ball and attaching a snap or button so that it will not craw back through.

\section{Obstacle Course}

A broon handle or sinllar object is used which is approximately three feet long.

\section{Ocular Pursults}

A pencil with a visible eraser is used.

\section{Visual Achievement Forms}

A plece of blank paper, approximately the size of typing paper (8:" $\times 11 ")$, a pencil, and the seven visual achlevement forms drawn on 4" $x$ 6" blank notecards were used.

\section{Rythmic Hriting}

A chalk board, chalk, an eraser, and the eight motifs drawn on

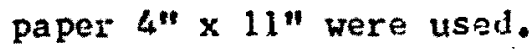


Name of child Date

Position held at agency

The statements beion describe various maladapt Ive behaviors found in enctionally disturbed children. The statements are meani: to describe behaviors. For example, If a statenent describes aggression, rate it according to ageressive behavior, regardless of the degree of aggressive feelings. Please rate each statement vith an "X" in the approprlate square after the statement. The squares are numbered from 1 to 5 and represent the degree to which you have noticed the described behavior. If you do not observe the child at night, marl those statements pertaining to night time behavior with an "o" in the (1) square after the statement. Please rate every statcment. The basis for making a judgment are given below:

(1) You have noticed riot noticed this behavior at all.

(2) You have noticed the behavior to a slight degree (it has occurred occasionally).

(3) You have noticed the behavior to a moderate degree (conmon behavior, occurs more than once a week).

(4) You have noticed the behavior to a considerable cegree (occurs every day).

(5) You have noticed the behavior to a very large degree (occurs more than once a day).

1. Hyperactive and restless

2. Very withdrawn.

3. Is upset by changes in rout ine

4. Fries often and easily

5. Appears confused by punishnent or correction

6. Destroys the belongings of others

7. Prefers to be by himself (plays by himsel $f$ )

8. Taslly distracted

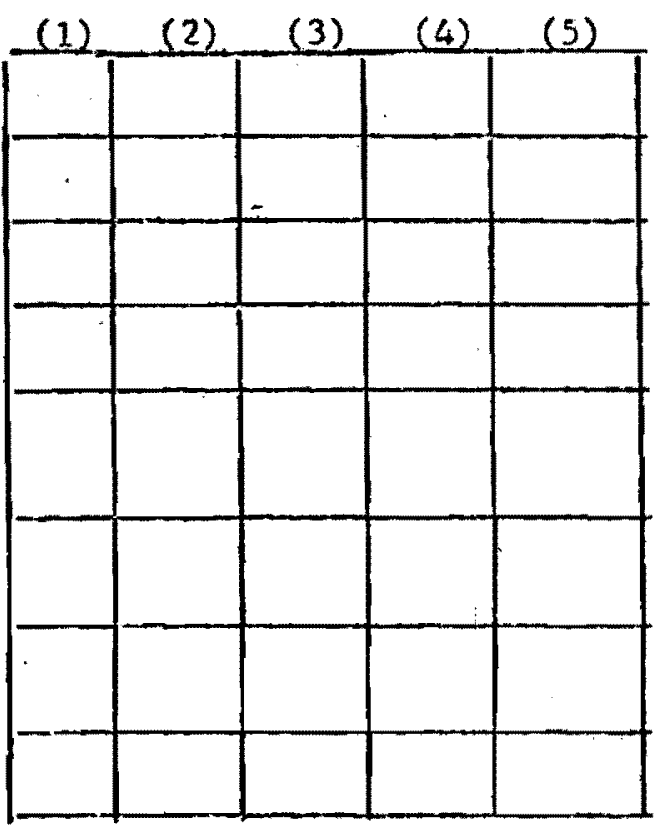


9. Appears confused in following directions

10. Has erratiç, flighty or scattered behavior

11. Demands a great deal of attention

12. Is aggressive foward other cirildren

13. Has explosive and unpredictable behavlor

14. Has difficulty reasoning things out

15. Daydreams often

16. Wets the bed

17. Wets pants during the day

18. Solls pants during the day

19. Is awakened at night with nightmares

20. Behavlor seems to go in cycles

21. Appears confused by structured activity (school)

22. Expresses unrealistic fears

23. Is aggresslve toward adults

24. Glves lllogical responses to questions

25: Cannot scom to control himself

26. Appears to inallucinate

27. Dostrons his om belongings

28. Appears not to be in this vorld"

29. Is generally uncooperative and stubtorn

30. Seerns generally unhappy

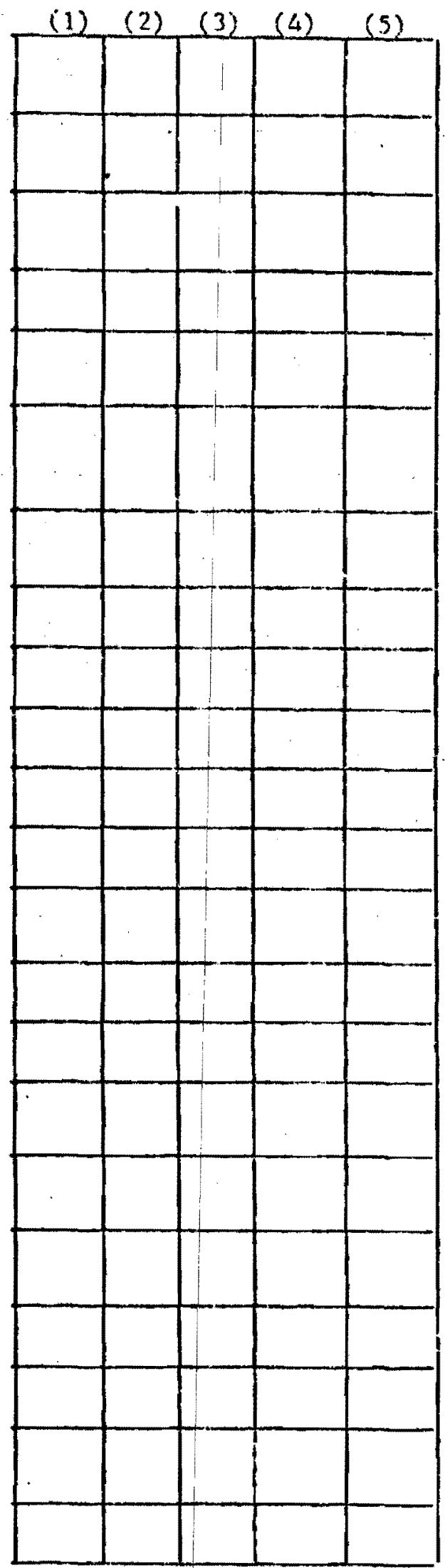




\section{APPENDIX F \\ HALL'S ANTI-SCCIAL SUESCALE}

Destroys the belongs of others

Is aggressive toward other children

Ilas explozive and unpredictable behavi or

Is agrressive toward adults

Destroys his own belongings

\begin{tabular}{|l|l|l|l|l|}
\hline & (2) & (3) & (4) & (5) \\
\hline & & & & \\
\hline & & & & \\
& & & & \\
\hline & & & & \\
\hline & & & & \\
\hline
\end{tabular}




\section{APPENDIK G}

BALL'S ASOCIAI SUBSCALE

Very withirawn

Prefers to be by himself

(play by hinself)

Daydreams often

Appears to hallucinate

Appears not to be in 'this world'

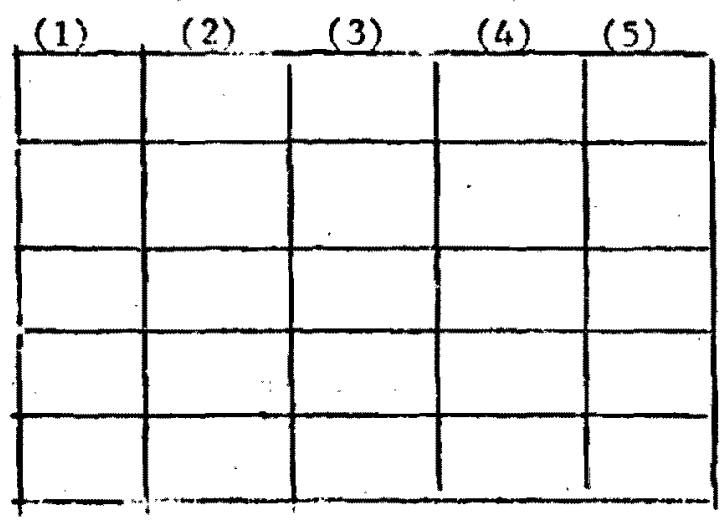


Balance Board

Date Accompl ished

\begin{tabular}{l|l|}
\hline 5" & 4" \\
\hline Marsden Ball & \\
\hline
\end{tabular}

Valking Poard

Forward

Baclward

Sidewlse

Turn

Ful1 Turn

Balance

Marsden Ball

1 Hand

Alternate

Botton

Bat

Balance Board

Chalkboard

$\checkmark$ Lolne

HLine

circle

1 Dot

Dots

Angels

Arms \& Legs

$1 \mathrm{LImb}$

Both Right \& Left

Cross Lateral ity

Count

Stomach 


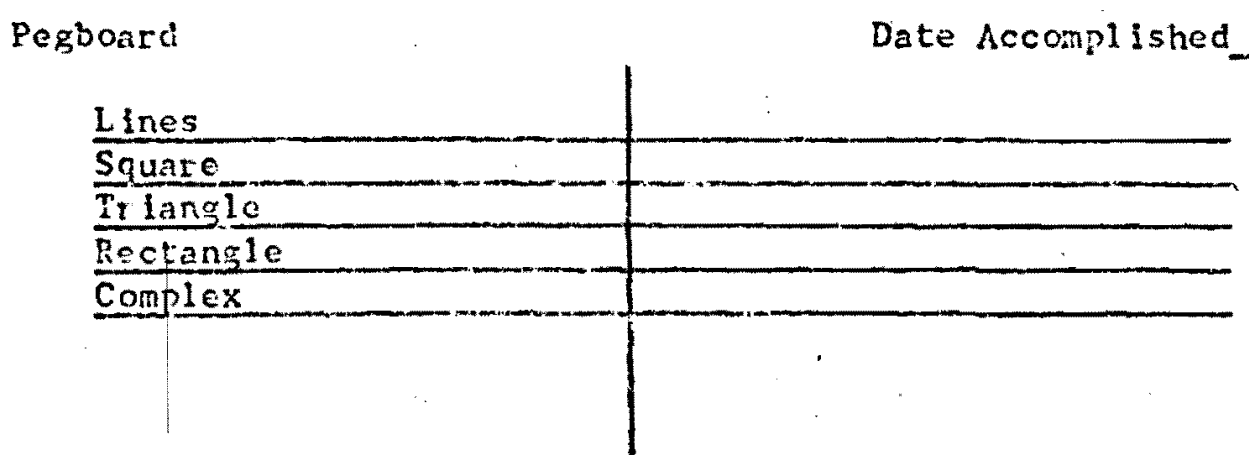


APPENDIX I

ACTIVITY RECORD (EXPER IMENTAL)

Name

Age

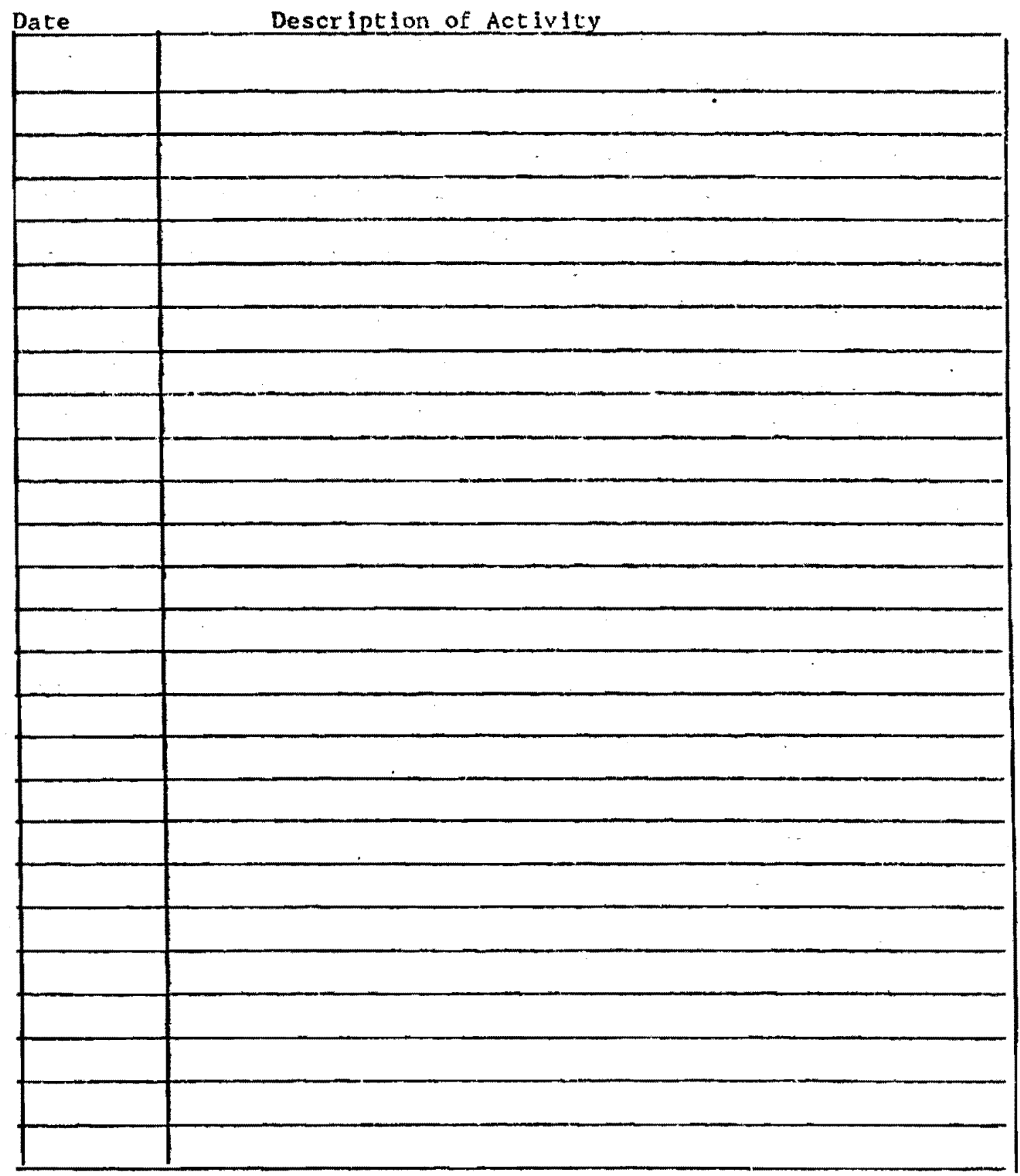




\section{APRENDIX $\mathrm{J}$}

\section{ACTIVITY RECORD (CONTROL)}

Name

Age

\section{DATE ACT TVIT:}

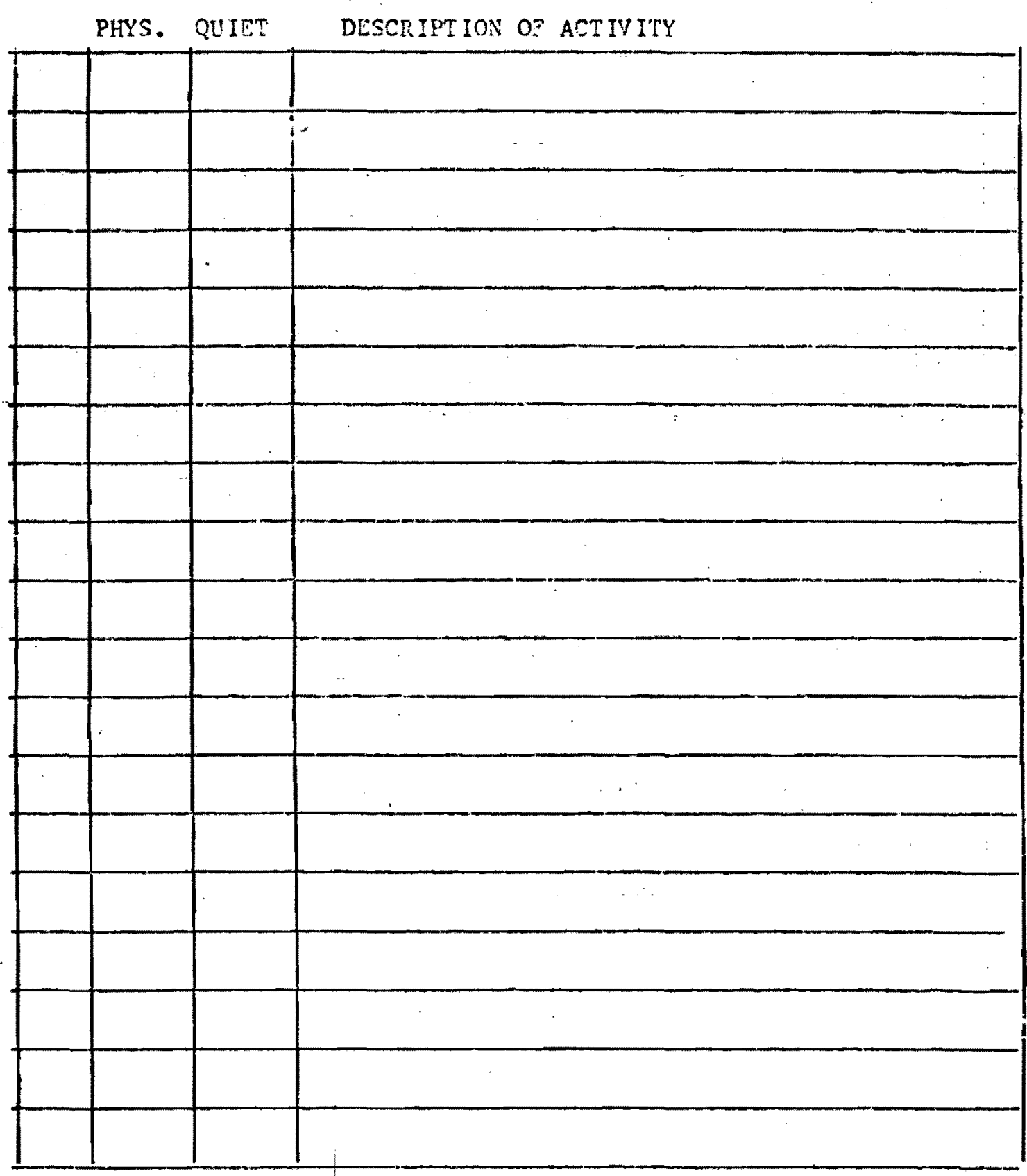


FUROUL PERCEPTUAT-MOYOR SURVLY

Name Date of Birth

Agericy $\operatorname{Sex}$

Magnos is

Test Dates

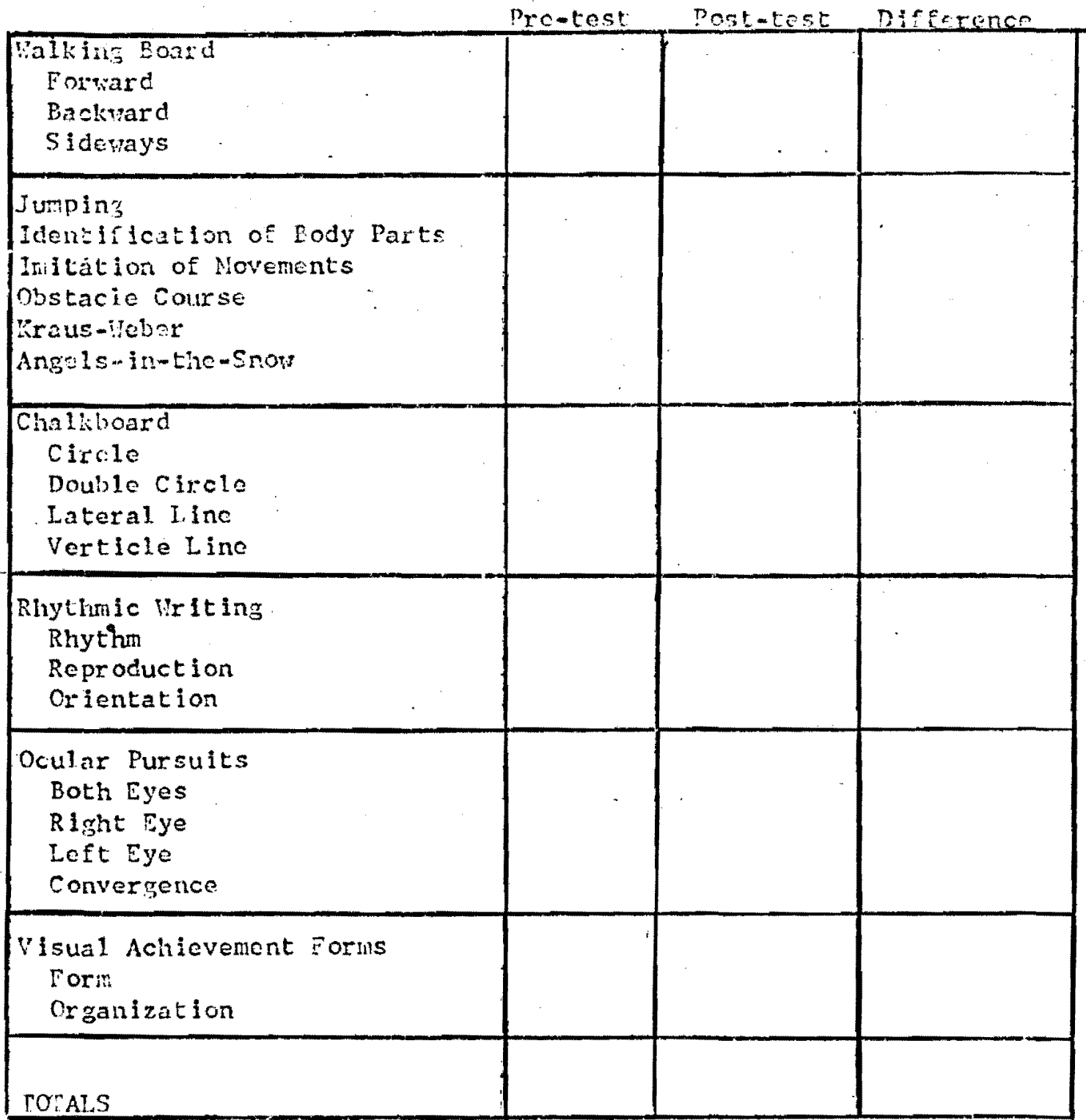


BEHAVIOR RA:TN SCALE SUISARY SHEET

Name Birth Date

Agency Sex

Diagnos is Rating Dates

Hyperactive and restless

Upset by changes in routine

Crics often and casjly

Confused by correction

Easily distracted

Confused in following directions

Erratic, flighty, scattered hehavior

Demands a great deal of attention

Difficulty reasoning things out

Wets bed

Vets pants during the day

Solls pants during the day

Is awakened with niglituras

Dehavtor seems to go in cycles

Confused by structured activity

Expresses unreal istic fears

Il Iogical responses to questions

Cannot seem to control himself

Generally uncooperative and stubborn

Seems generally unhappy

Very withdrawn

Prefers to be by himself

Daydreams often

Appears to hallucinate

Appears not to in 'this world' Asocial Sub-Total

Destroys the belongings of others

Is agzressive toward other children

Explosive and unpredictable behavior

Is aggresslve toward adults

Destroys his own belonglings

Ant1-Sociel Sub-Total

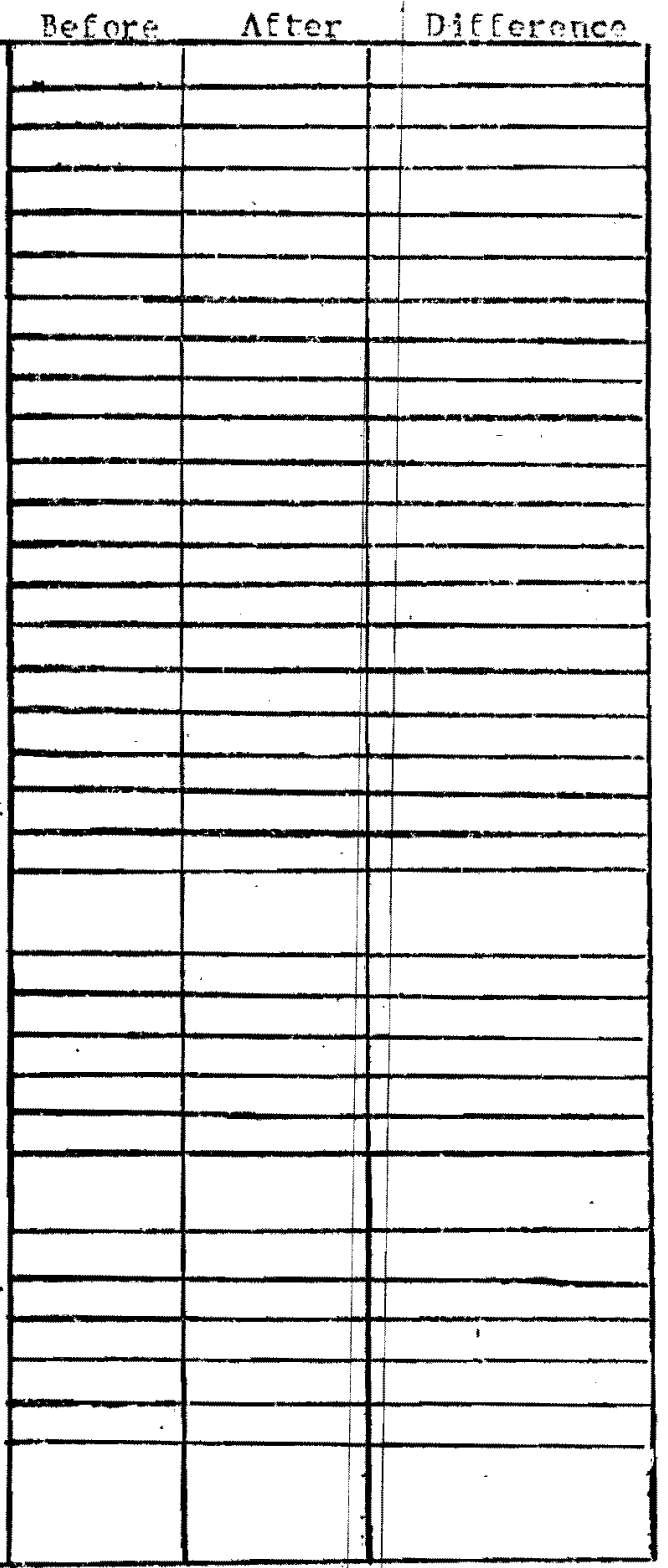


APPENDIY 1

RAI DATA 
TARLE XIII

EA: SCONES

P. ‥ A. Tot. Behnv, AntiAsoc,

Subi. Pie Post Pre Post Pro Post Pre Post

TWPERTITITAL

$\begin{array}{llllllllll}\text { yithdram } & 1 & 32 & 60 & 240 & 209 & 22 & 22 & 58 & 51\end{array}$

$\begin{array}{lllllllll}2 & 55 & 68 & 204 & 186 & 24 & 22 & 51 & 44\end{array}$

$\begin{array}{lllllllll}3 & 40 & 7 & 300 & 247 & 40 & 38 & 62 & 46\end{array}$

$\begin{array}{llllllllll}4 & 32 & 52 & 219 & 193 & 24 & 34 & 48^{-} & 32\end{array}$

$\begin{array}{lllllllll}5 & 65 & 84 & 194 & 145 & 22 & 21 & 38 & 25\end{array}$

$\begin{array}{llllllllll}\text { Acting out } & 6 & 47 & 71 & 282 & 202 & 61 & 51 & 37 & 34\end{array}$

$\begin{array}{lllllllll}7 & 57 & 64 & 164 & 145 & 37 & 30 & 26 & 20\end{array}$

$\begin{array}{llllllllll}8 & 67 & 75 & 196 & 195 & \ldots & 47 & 43 & 18 & 20\end{array}$

$\begin{array}{lllllllll}9 & 55 & 72 & 241 & 231 & 48 & 48 & 32 & 33\end{array}$.

$\begin{array}{lllllllll}10 & 52 & 73 & 250 & 197 & 51 & 35 & 30 & 23\end{array}$

CONTROL

$\begin{array}{llllllllll}\text { Withdrawn } & 11 & \ldots & \ldots & 216 & 227 & 33 & 35 & 31 & 37\end{array}$

$\begin{array}{lllllllll}12 & 37 & 38 & 228 & 221 & 27 & 21 & 44^{\circ} & 45\end{array}$

$\begin{array}{lllllllll}13 & 34 & 31 & 202 & 196 & 21 & 25 & 42 & 38\end{array}$

$\begin{array}{lllllllll}14 & 27 & 37 & 206 & 208 & 25 & 28 & 49 & 41\end{array}$

$\begin{array}{lllllllll}15 & 66 & 66 & 148 & 135 & 19 & 22 & 35 & 30\end{array}$

$\begin{array}{llllllllll}\text { Acting out } & 16 & 51 & 59 & 241 & 240 & 53 & 44 & 37 & 34\end{array}$

$\begin{array}{lllllllll}17 & 66 & 73 & 187 & 178 & 47 & 42 & 24 & 22\end{array}$

$\begin{array}{lllllllll}18 & 54 & 66 & 210 & 201 & 44 & 40 & 25 & 25\end{array}$

$\begin{array}{llllllllll}19 & 27 & 33 & 280 & 279 & 43 & 45 & 43 & 43\end{array}$

$\begin{array}{lllllllll}20 & 64 & 63 & 172 & 168 & 28 & 31 & 27 & 27\end{array}$ 


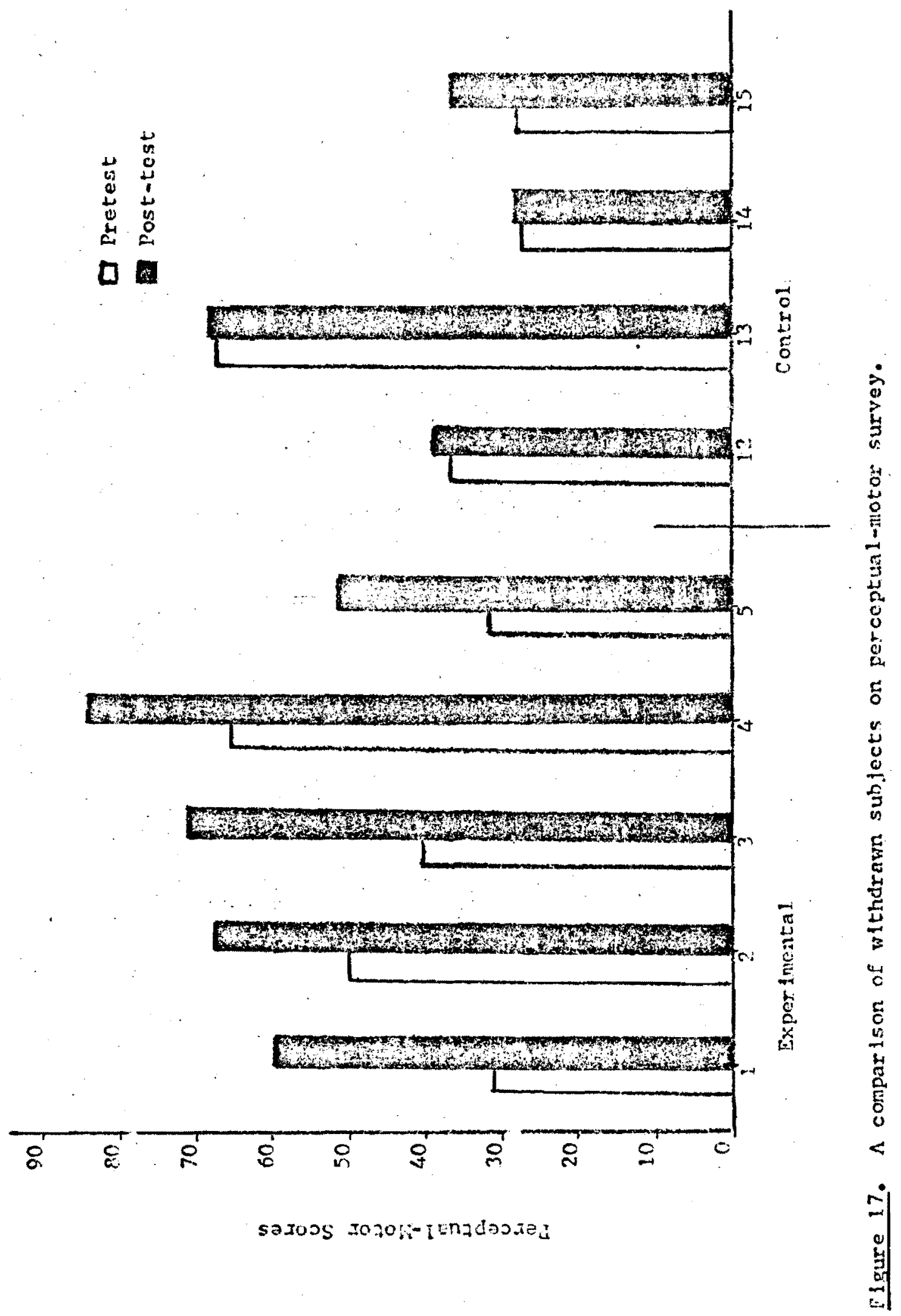



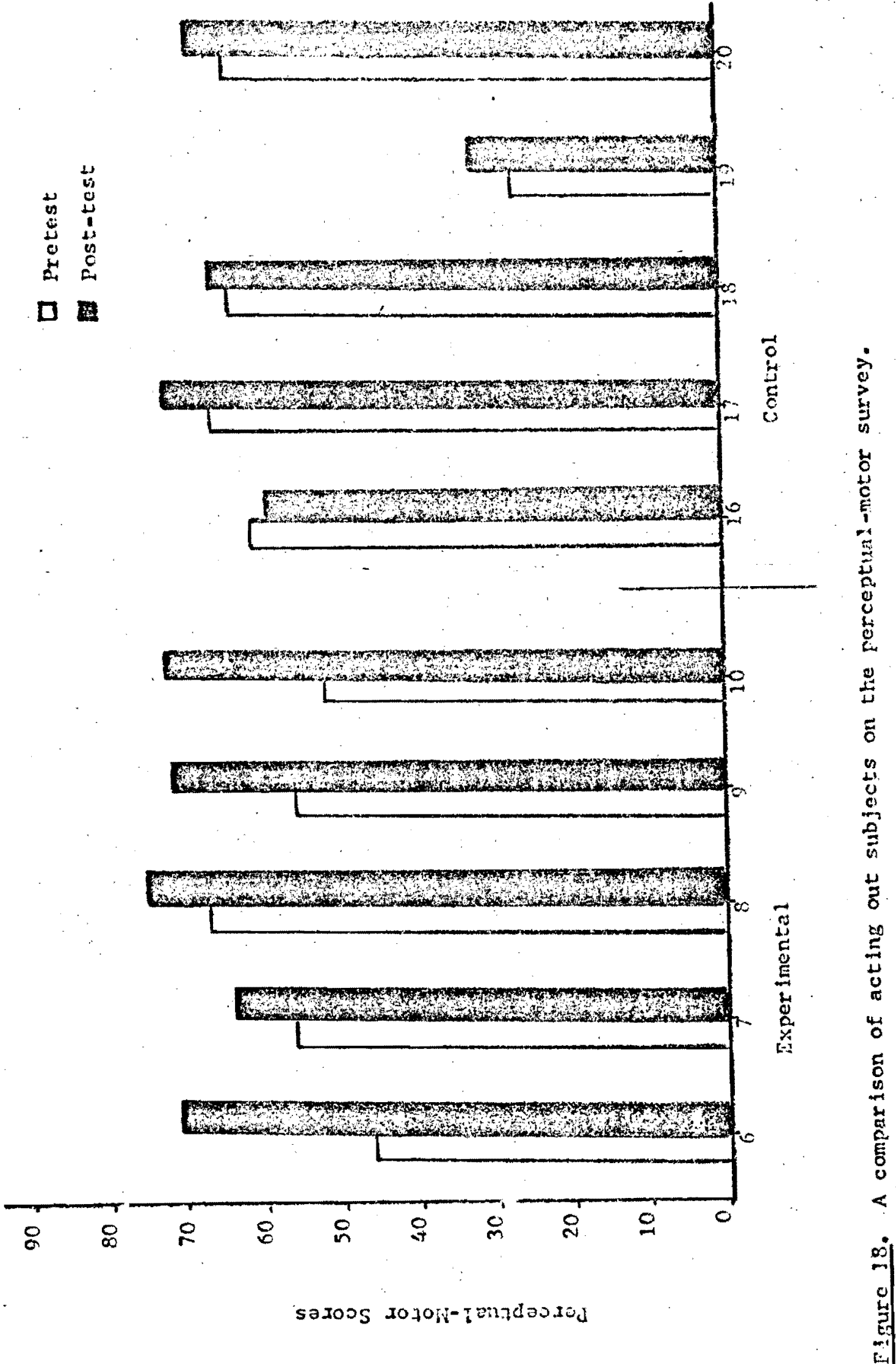


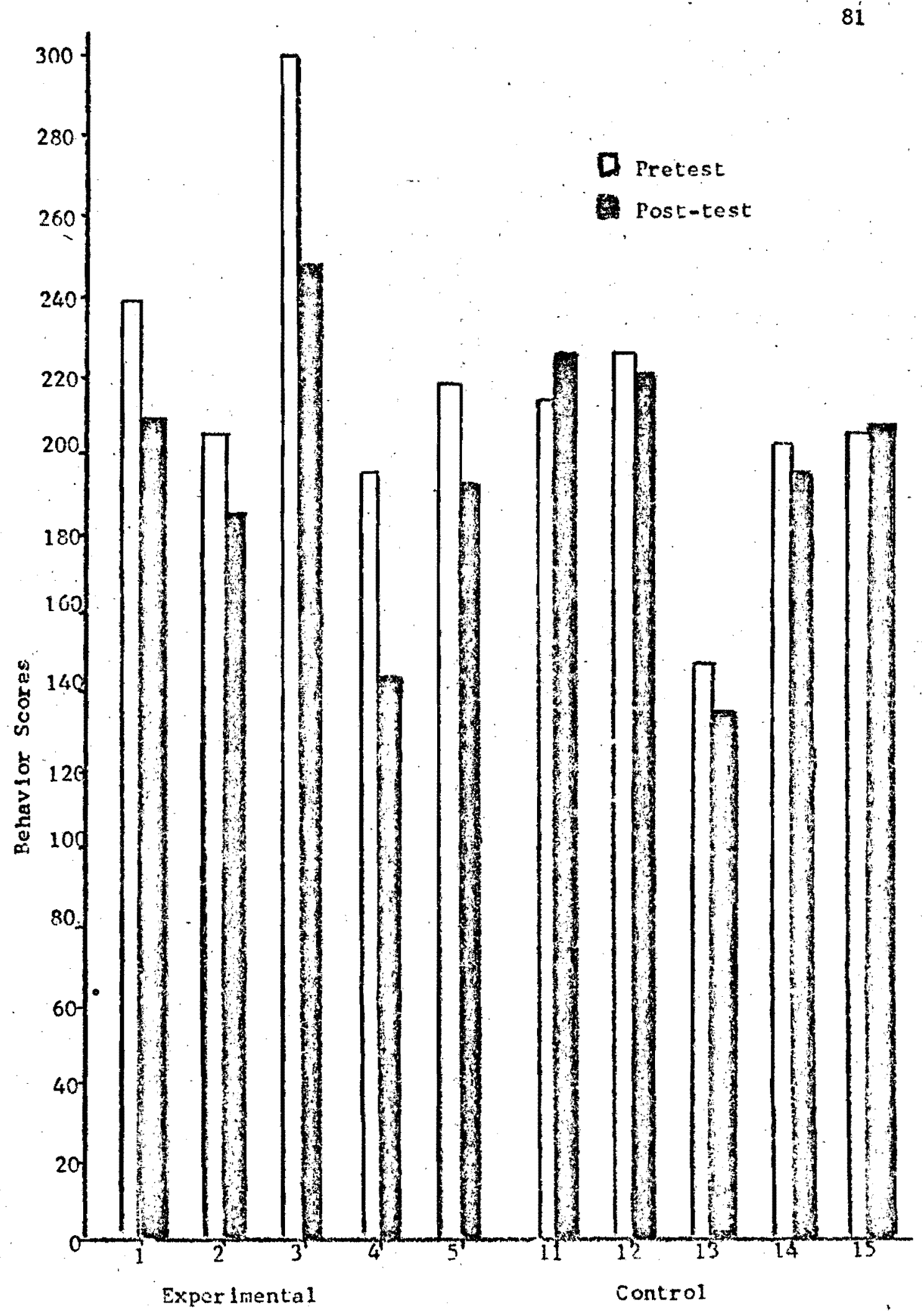

Figure 19. A comparison of withdrawn subjects on the behavior rating scale. 


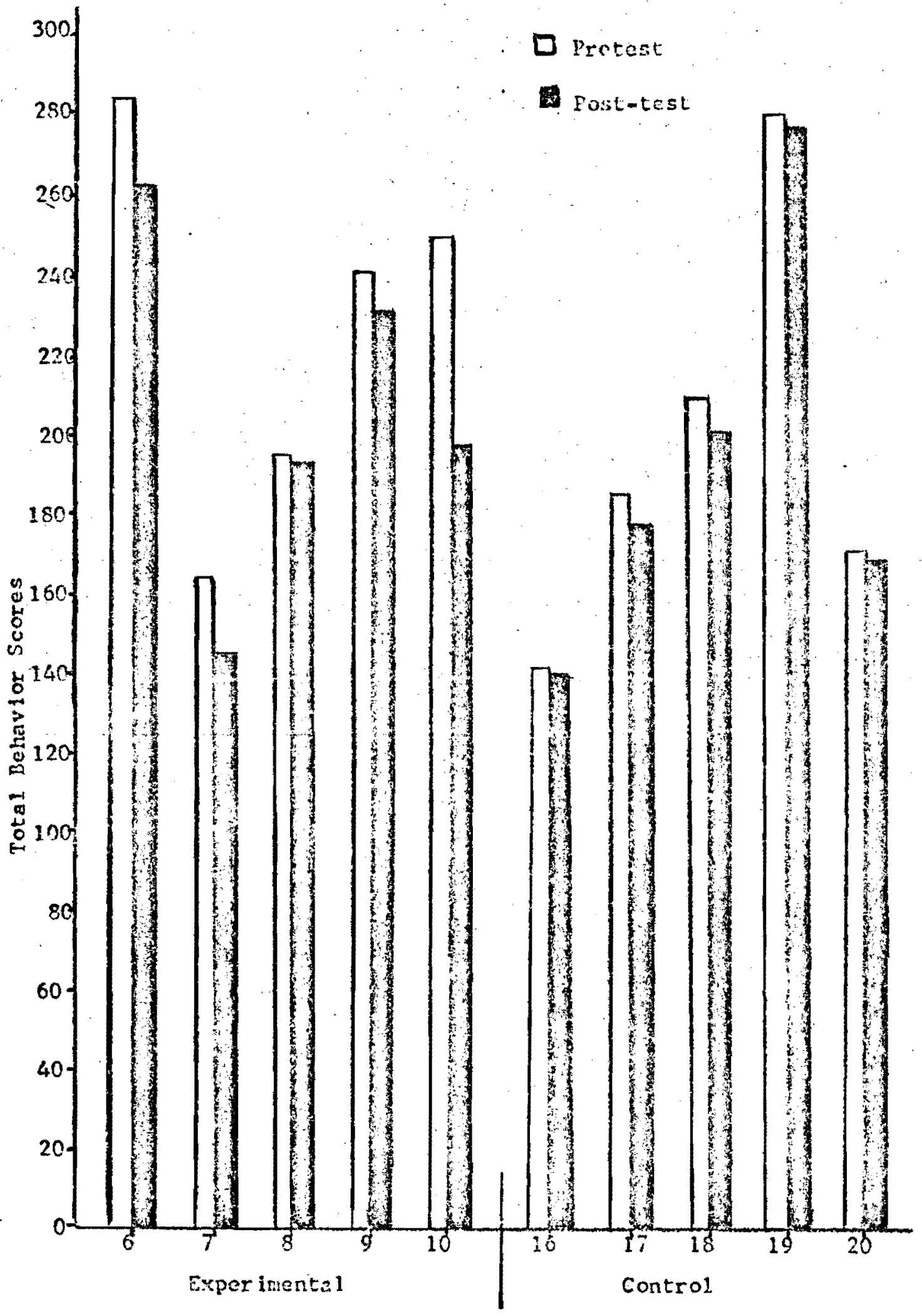

Floure 20. A comparison of acting cul sublects on the behavior rating scale. 


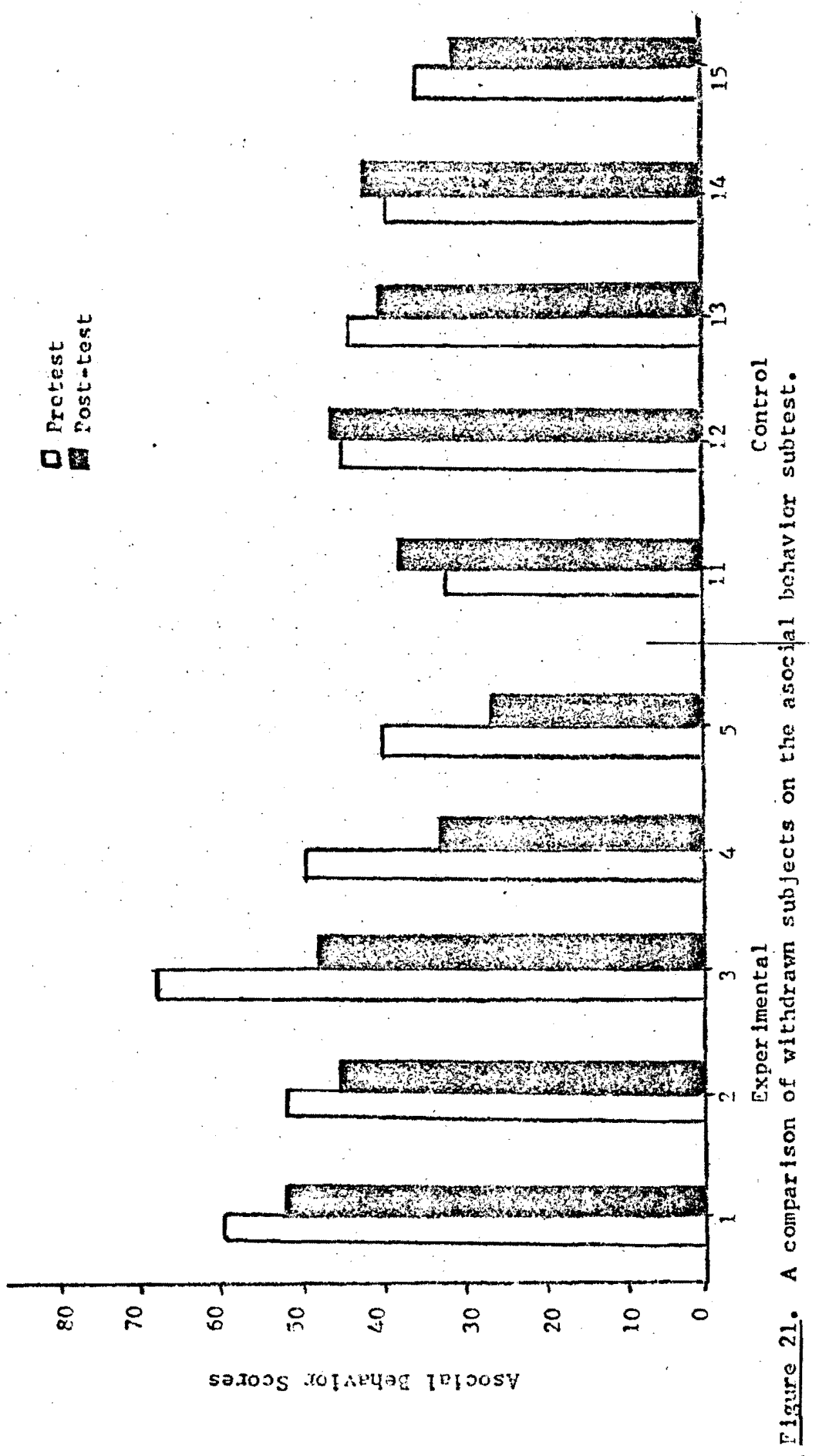




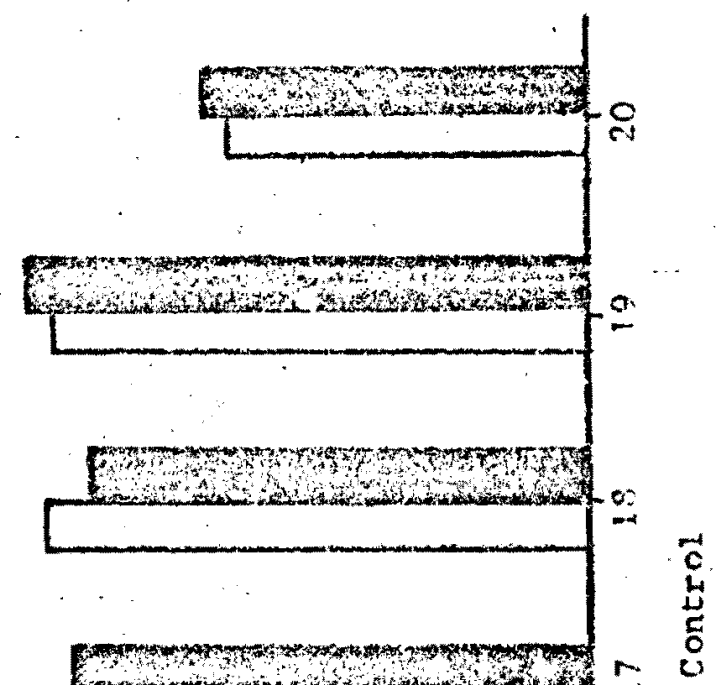

\section{口间}

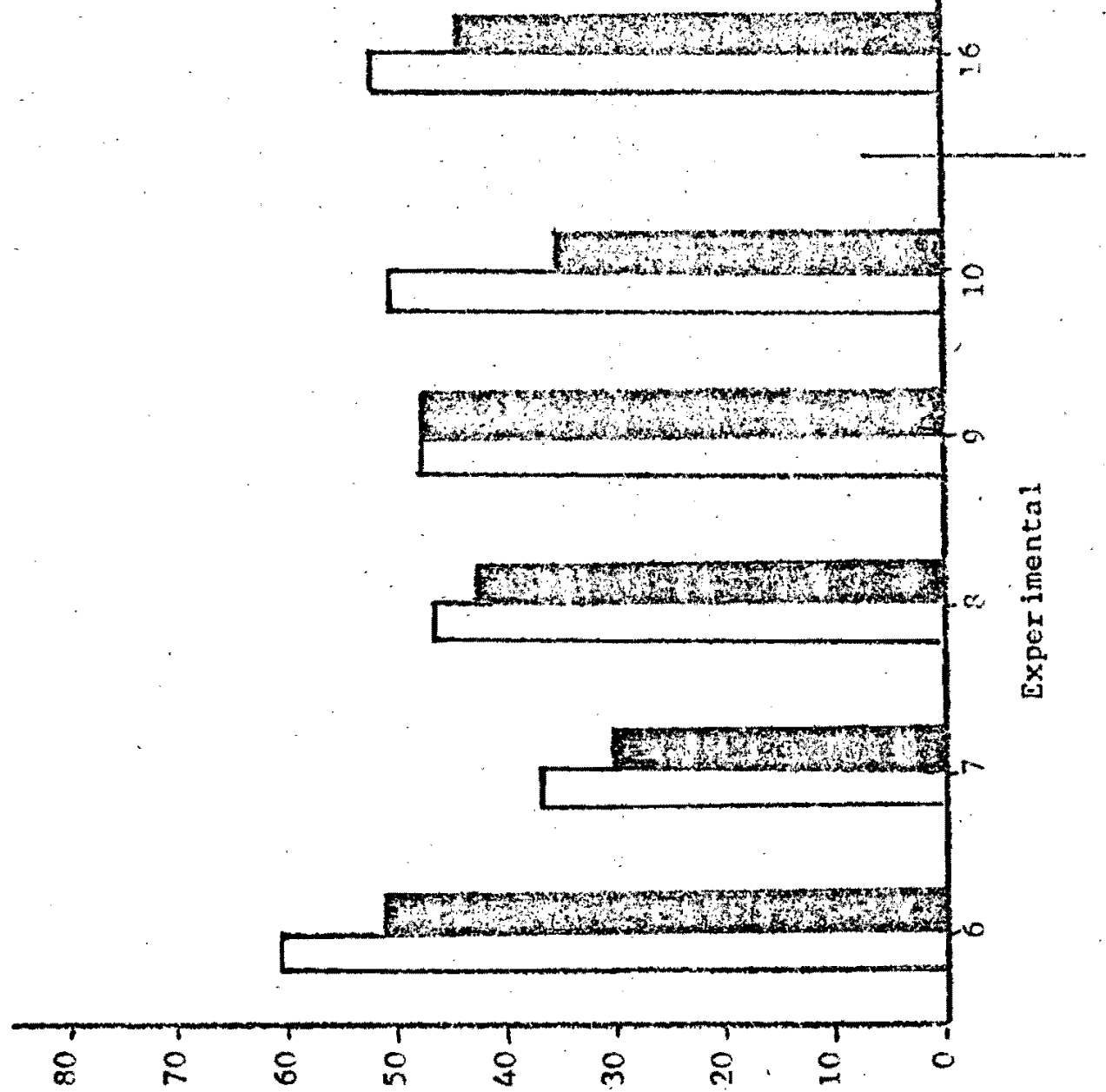

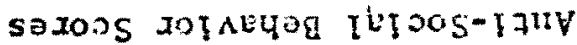


APPENDIX M

WAVERLY NEUSLETTER ARTICLE 


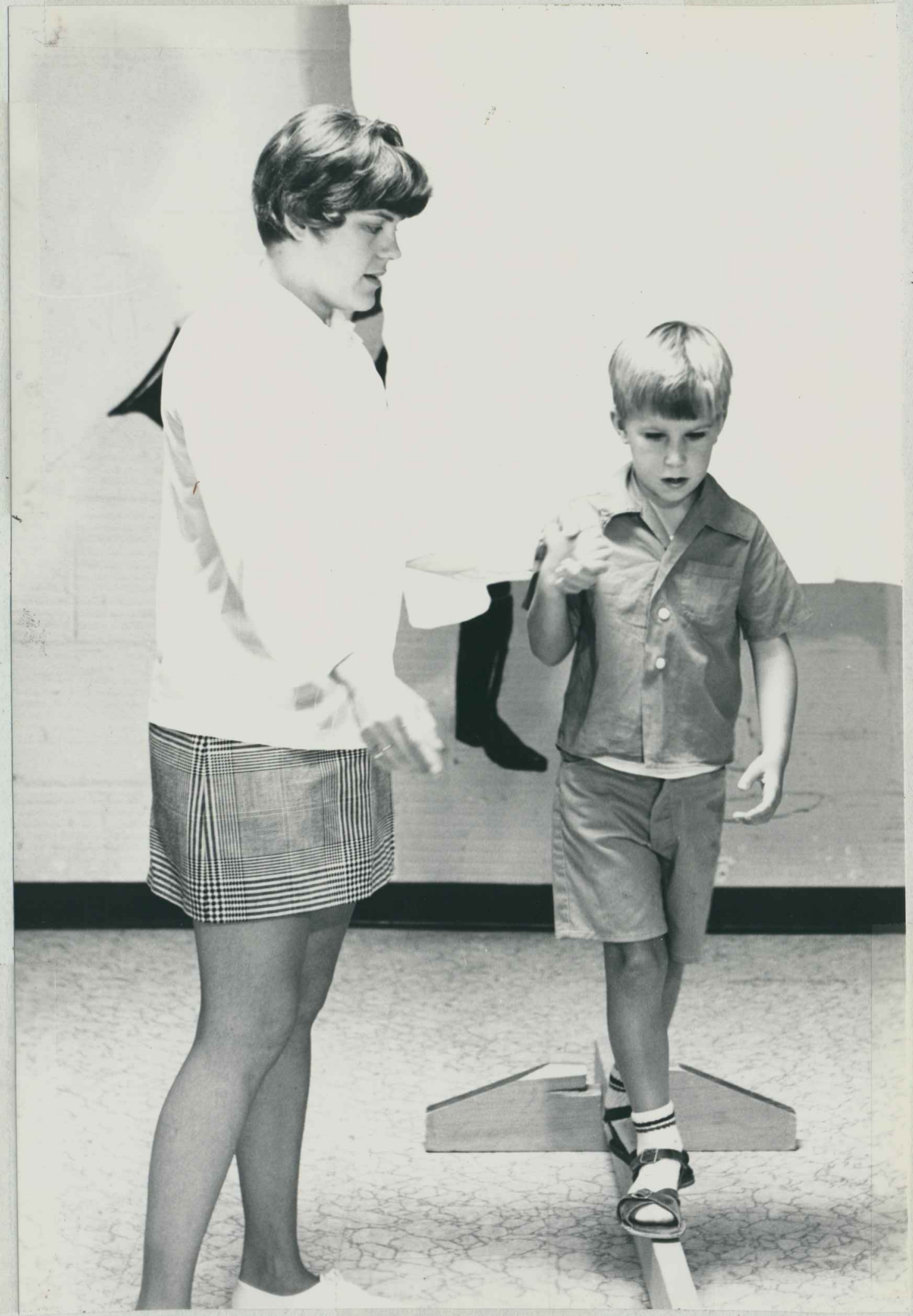

Niss Julia tall working with a boy on Perceptual-Notor training. 


\section{PERCEPTUAL-MOTOR TRAINING}

During the last nine weeks we have been helping Jul ia Hall Wh her research study for her masters thesis. Miss Hall recelved her Bachelors of Science in psychology from the University of Oregon in 1968. She worked wth emotionally disturbed chlldren at Parry Center and has plans to complete her Masters of Sclence in psychoiogy from Portland State University this sunmer.

The purpose of Miss hall's study is to determine whether a Perceptual-Motor Tralning program as designed by D. H. Radler and Newe: : C. Kephart in the ir book Success Through Play will effect a decrease in the amount of maladaptive behaviors exhibited by emotion. ally disturbed children. She hopes to discover whether these training techniques will be valuable in the treatment of these chlldren. It is also her hope to be able to discover with what type of behavior this training is most effective.

Miss Hall is working with twenty children between the ages of six and trelve from three agencies in the Portland Metropolitan area. Eight of Haverly's children are participating in her study. Vlaverly has used Perceptual-Notor training in the form of walking boards, lacing boards, and puzzles quite successfully for the last three years with our retarded children. We are all interested in the result of Miss Hal1's study as a possible new resource for helping the emotionally disturbed chlld.

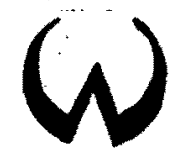

WAVERLY CHILDRENS HOME

3550 S.E. Woodward

Portland, Oregon 97202

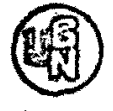

